Estonian Journal of Archaeology, 2006, 10, 2, 99-131

\title{
Kristiina Johanson \\ THE CONTRIBUTION OF STRAY FINDS FOR STUDYING EVERYDAY PRACTICES - THE EXAMPLE OF STONE AXES
}

\begin{abstract}
The following article gives an overview of the stone shaft-hole axes dated to the Neolithic and Bronze Age which have been gathered randomly from the area of present-day Estonia. While the group of artefacts under discussion forms a big part of the material culture of the respective periods, special attention is paid to the analysis of possible deposition contexts of the stray finds in order to get closer to the settlement, economy and social relations of the time. The main purpose of the article is to interpret the last find place of the axes as a possible settlement, burial place, offering site or the place of secondary deposition. The probable motives behind the activities that led to the deposition are suggested. Next to the contexts of the Stone and Bronze Age, attention is also paid to the belief in "thunderbolts". As widely accepted, stone shaft-hole axes have also been considered "thunderbolts" in Europe, Asia, Africa and America during the Middle and Modern Ages. Arguments are given to date the beginning of the belief in Estonia.
\end{abstract}

On käsitletud Eesti alalt kindla leiukontekstita kogutud neoliitikumi ja pronksiajaga dateeritud varreauguga kivikirveid. Kuna antud esemerühm kujutab endast suurt osa vastavate perioodide säilinud materiaalsest kultuurist, on erilist tähelepanu pööratud juhuleidude võimalike ladestamiskontekstide analüüsimisele, et sedakaudu jõuda lähemale kõnealuste ajajärkude asustuspildile, majandusviisile ja sotsiaalsetele suhetele. Artikli peamiseks eesmärgiks on juhuslikult leitud kirveste viimase leiukoha tõlgendamine asulakoha, kalme, ohverdamiskoha või sekundaarse depositsiooni paigana. On püstitatud oletusi viimasele ladestamisele eelnenud või sellega kaasnenud tegevuste kohta. Kiviaegsete kontekstide kõrval on tähelepanu pööratud rahvapärimusest tuntud usule kivikirvestest kui "piksenooltest", esitades argumente selle laial alal levinud uskumuse dateerimiseks Eesti territooriumil.

Kristiina Johanson, Chair of Archaeology, Department of History, University of Tartu, 3 Lossi St., 51003 Tartu, Estonia; kristiina.johanson@ut.ee

For most archaeologists, material culture means simply artefacts, things, reminding of dry typologies, objective measurements of angles, length, sharpness, weight and breadth, distribution patterns... At the same time social patterns, religious systems, ritual behaviour and different everyday activities have been separate issues, the reconstruction of which requires more than is possible to deduce from material culture. I cannot confute the idea as a whole, naturally, as material culture IS about physical parametres of things, but it should not be 
forgotten that there is much more to consider. So, we could turn to the more theoretical and sententious stories about the soul and the life-cycle of an artefact, for example an axe. According to many researchers (Appadurai 1986, 4; Andersson 2004, 188; Tilley 1996, 247) things in the pre-industrial cultures have biographies like people: they are produced (birth), exchanged (socialization), used (life in general), destroyed (death, killing) and finally deposited (burial). However, the concept of the biography of artefacts itself stresses that an artefact has a meaning for a person only when he percieves/senses it (prepares, watches, touches, buys, sells, exchanges, destroys, repairs, deserts or even thinks about it). Material culture does not mean anything before it has been incorporated into interpretation or, to put it differently, into the process of percieving. Thus it should be said that in the current article, the artefacts are not alive, they do not have a certain biography, their function, meaning and value depends on the person to whom it belongs. Rather we should look at archaeological items as "events from the past that have preserved until today" (Andersson 2003, 63, my emphasis) or agree with Earle (Earle 2004, 114) that "an artefact is something that happened in the past, but, unlike other historic events, it continues to exist".

In the following I will make an attempt to demonstrate how inanimate things, obtaining their meaning only through the actions, thoughts and perceptions of people, can actually offer much useful material to contemplate on the ritual and daily life of the past. My attempt is made more complicated by the fact that I have chosen mostly totally context-free items - stone shaft-hole axes gathered as stray finds. In total I have gathered information on 820 stone shaft-hole axes that have been collected on Estonian territory, the overwhelming majority of which are stray finds, but among those I have also included the material obtained from known graves and settlement sites. The supposed number of axes belonging to different contexts (settlement, grave, offering place, place of secondary deposition) is given in the following sections.

\section{Source material - stone axes}

The period of making and using the shaft-hole axes of stone in northern Europe is dated to a relatively long period from the Neolithic to the Bronze Age. According to the present state of research in Estonia, we can speak of making stone shaft-hole axes from approximately 3200 years BC, i.e. Late Neolithic. The producing and using of stone axes has continued well into the Bronze Age, until around 1000 years BC, but probably even the 2nd half of the Pre-Roman Iron Age approximately 100-200 years BC, when the majority of jewellery, tools and commodities were already largely produced of iron (Lang, in print). The stone shaft-hole axes under discussion embrace boat-shaped axes ${ }^{1}$ of the Late Neolithic

1 It should be at this point that the term "boat-axe" is rarely used in other countries. For example in Scandinavia and western Europe the axes are called "battle-axes" (stridsyxe in Sweden, stridøkse in Denmark and Norway). 
Corded Ware Culture (CWC), the simple shaft-hole axes which are probably partly contemporary and partly later than the boat-axes, and late shaft-hole axes which can be dated to the Bronze Age. The typology does not play any important role at this point, since although the types of shaft-hole axes differ much (for example the beautifully and skilfully finished boat-axes in comparison to later or contemporary simple stone axes (i.e hammer-axes)), I believe that we are dealing with different stages of one and the same tradition, thus we can speak of continuity. This would mean that we can expect certain similarities in the ways how the artefacts were percieved, the rules of their production, use and deposition. Therefore their finding predominantly as single finds might indicate at a common practice and similar motives behind the actions. Still, we might take a quick look into the state of present research concerning the period of the shaft-hole axes, to create the necessary background for the axes.

In Estonia we know of a little more than 50 settlement sites from the CWC. The number of burial sites stays around 20 and has not changed much during the last 60 years or so. The latter are mostly discovered while digging for gravel and are thus often partly destroyed and have hardly ever been properly and scientifically researched. The CWC sites cannot be easily located, as they do not offer many finds, and have a weak cultural layer (Jaanits 1966, 63). They are situated differently from the previous Mesolithic and Early and Middle Neolithic sites with the settlements orientated more towards inland areas.

The following period - the Early Bronze Age - is on the other hand extremely poorly represented by settlements and burial sites. People undoubtedly continued living in previously inhabited places. Besides very few settlements we do not know any burial sites from the period. The situation changes with the Late Bronze Age with numerous stone-cist graves and fortified settlements.

Anyway, the numerous randomly found shaft-hole axes make up a majority of the material culture of the Late Neolithic and the Early Bronze Age, for the latter case to an overwhelming extent. The biggest problem is that they are found alone, without any associated finds, mostly in the fields while ploughing, but sometimes from water, bogs, forests or elsewhere. So far their interpretation has been neglected or considered unnecessary due to their "uninformativity". When their possible contexts have been discussed, the result has perhaps been over-simplified, for example they have been considered as indicating a settlement site nearby (Lang 1999a, 333) or the only preserved trace from an unnoticed or destroyed burial (see Jaanits et al. 1982, 107; Huurre 1998, 276). My idea is that although more or less entirely contextless for archaeologists, these axes have been once produced, used, reworked, destroyed, buried or deposited in some other way, thus they have singular histories connected with the people who owned and/or used them.

Thus, in order to find a way into the minds of the people of this prehistoric time, one way is to look for the profane or religious ideas behind the deposition of a single group of artefacts, e.g stone axes, by considering their looks (damaged, intact, broken, etc.), their find context (settlement site, burial, offering place) and the geographic landscape in which they have been discovered. 


\section{Terms and categories}

One of the important aspects in studying religious contexts is to discuss the terms. We use words like religious, ritual, magic, sacred, holy, spiritual (meaning unusual, extraordinary, fascinating and unperceived) to distinguish them from terms like profane, everyday, secular (meaning comprehensible, easily understood, common, maybe even boring). The terminological and contradictory multiplicity is increaced by prestige vs everyday. As for the boat-axes, their beautiful and careful finish has disqualified them from work implements, quite the opposite, they have been regarded as possessing prestigious, ritual, symbolic meaning (Malmer 2002, 155). It is especially conspicuous regarding the $\mathrm{CWC}$ where a clear-cut distinction is made between the work-axes and boat-axes (for example Лозe 1979, 68; Huurre 1998, 276). In many cases we are actually dealing with a truism: when something is beautiful and excellently finished, it has to be prestigious and hence not suitable for practical functions. I agree that there are examples of big-size and ostentatious axes that cannot be used for practical work, and axes with too small shaft-holes which could not hold a shaft, but these examples hardly dominate. The majority of the material shows traces of practical usage. The more beautiful and elaborate boat-axes were probably never used for clearing the landscape for fields, mollifying the soil or felling trees, the practical usages most commonly considered for the stone shaft-hole axes. Instead, their worn surface but otherwise correct proportion (which actually indicates that the axes could not have been used constantly for any of the above-mentioned purposes) reveals that they were carried along for a long time, but cared for and not "wasted"! At the same time the simple shaft-hole axes are often worn to a remarkable degree, sharpened many times and have thus lost the initial "proper" proportions. Thus we might conclude that they have been used in some practical way. The carefully finished and proportional late shaft-hole axes probably share the usage of the boat-axes. Nevertheless, I argue that the meaning and importance of the axes to their users/owners had to be rather similar regardless of their looks, the reason being their work value - value that arises from the work that the production of the item requires (see Renfrew 1986, 157). A similar meaning might be indicated by their similar find contexts which retrospectively lead back to similar deposition practices.

I will now return to the problem of the mentioned words and dichotomies and the need for clear-cut categories. During the last decade, especially in the research of material culture both on abstract and theoretical level, as well as when illustrated with particular examples, archaeologists have been concerned with determining whether and how much these classifications and categories are actually justified. Processual archaeology has been much criticized as processualists separated context from form and function: whereas the latter two were closely connected, context was not included in the research (Vandkilde 2000, 7). For example Lewis Binford divided artefacts between three classes - technomic, sociotechnic and ideotechnic, that functioned for dealing with environmental, social and ideological matters respectively (Shanks \& Tilley 1987, 87). Without 
going deeper into the categories, it is apparent that Binford saw a sharp distinction between items with practical function and those with religious meaning (Vandkilde 2000, 7). Similarly, Michael Schiffer has ascribed three types of functions to artefacts: (1) techno-function that includes obtaining resources, processing and preserving, technological processes, fulfilling people's biological needs; (2) sociofunction that affects symbolically social communication; and (3) ideo-function that symbolizes ideology and carries other information (Schiffer 1987, 4). Although already Schiffer mentioned that most of the artefacts accomplish more than one function (ibid.), especially the contextual direction of the postprocessual, archaeologies started to emphasize that the utilitarian and symbolic tasks of material items are not in contradiction but rather depend on each other and on the context. The function of the artefact is part of its symbolic meaning and they are both intentionally scattered inside the idea of context (Hodder 1986, 130). Analogously, while explaining the dichotomy of ritual/domestic or sacral/profane it has been recognized that all material culture is laden with symbolic meaning that makes it extremely difficult or even pointless to distinguish between sacral and domestic (Garwood et al. 1991, viii).

As mentioned, ideas expressed in material items are neither intrinsic to them nor unchangeable, they rather acquire their meaning through practice and are dependant on context (Bradley \& Edmonds 1993, 14). This attitude is complemented by studying material culture as text which gets its meaning only through context. Julian Thomas, for example, has observed the burial of the Bell Beaker Culture as a practice where individual items, gestures and actions were probably worthless separately but they were important nevertheless as they contributed to the creation of the general burial context (Thomas 1991,33). Thus, one item, while moving in different contexts, could freely acquire new meanings and leave behind the old ones. This in turn would mean that the question of what exactly a single axe could mean, is really pointless, because the answer would be "all and nothing". In other words, material culture is like a polysemantic text implying that the meaning of an artefact can never be explained to the end (Shanks \& Tilley 1987, 117).

The above proves that distinguishing between meaning and function is futile as they represent different sides of the same coin (Räf 2000, 240) ${ }^{2}$ and after some time the symbolic role of a once practically used item might be its new function. A good example at this point is a thunderbolt - a Stone Age item that has exchanged its past practical purpose for protective magical role.

Likewise one cannot separate the value (costliness) of an artefact from its function and suppose by default that an item with practical function was more

2 Actually function and meaning cannot be sometimes separated at all, because is referring to identity (belonging to a group) actually the meaning or the function of an artefact? Although artefacts can be used differently, they are normally employed in one way only, so most of the artefacts have been produced for one purpose (which according to Shanks \& Tilley 1987, 92) is functional, for example a chair for sitting). But if this primary function is not functional (practical), then the primary purpose should be meaningful. But to what extent is function practical? And at what moment exactly does functional turn into meaningful? 
worthless. Colin Renfrew has suggested three types of value that are ascribed to artefacts: (1) prime value - value for an arbitrary reason, for instance rare material, other attractive quality (gold, amber, beautifully cast copper or bronze, etc.), this can be called prestige value; (2) use value - material is valued for itself, its usage potential and practical qualities; (3) work value - value that arises from the work that the production of the item requires (Renfrew 1986, 157). Of course these are again categories that are not absolute, the presence of one (prime, work value) does not exclude the other, and this is proved by numerous archaeological and ethnographical examples.

Helle Vandkilde has suggested in case of the first Late Neolithic copper axes that there are no clear-cut categories between display axes and work axes, as both the richly embellished as well as undecorated axes have been quenched in the same way, thus their functional potential is not different. At the same time most of them reveal numerous damages to the blade and many have been quenched and repaired through re-quenching and adding tin (Vandkilde 1996, 268 f.). Ethnographic material has also shown why definite categories may not work, namely the stone axes of New-Guinea mountain region have been divided into three: ceremonial axes, bride payment axes and work axes (see for example Coope 1979), but their more thorough typological research showed that the axes formed an integral whole both in form as well as function, and there could not exist any straightforward categories. ${ }^{3}$ Thus the most beautiful bride payment axes could be used to cut trees and the most common ones had a certain prestige value among the lowest social groups (Vandkilde 1996, 266). In her research of Portuguese copper age stone axes, Katina Lillios has shown that amphibolite axes were used as valuables to extend social influence. From the material the emerges on a comparatively limited area and is difficult to obtain, necessary tools were produced for agricultural people - axes, adzes, chisels and hoes; the status of elite involves control or restricted access to raw material. At the same time many unused axes and limestone imitations of amphibolite tools have been found from graves that seems to indicate their prestige and ritual value (Lillios 1993, 113). Ethno-archaeological parallels of Nepalian copper items speak the same language: household copper artefacts have both functional, as well as utilitarian extent, although they are involved in rituals of honouring gods and offering to them. A copper item used in such contexts is not disqualified from usage in other contexts (Anfinset 2000, 210).

Several examples can be found among artefacts that are supposed to have one single definite function but which are nevertheless used in different practical ways. Middle-European Linearbandkeramik Culture includes the so-called shoe-last axes

3 Actually, Coope saw a big difference between work axes and ceremonial axes regarding their form (size, decoration) but not the function. In New Guinea both work, as well as ceremonial axes were used in war and on the Solomon Islands axes were exploited for cutting trees, building canoes and waging war, although today (since the 1950s metal axes) they only have a ceremonial role (Coope 1979, 112). 
that have generally been connected with land clearing practices for agricultural purposes; their distribution to North-German, Danish and South-Swedish Mesolithic Ertebølle Culture (although to a quite limited extent) is regarded as a sign of direct contacts with agricultural people. From a Linearbandkeramik settlement in Talheim (Heilbronn) skeletons of 34 people were found who had been killed at the same time during a military conflict and buried in a mass grave. The shapes of the wounds indicate that at least 22 lethal blows to their skulls had been given by 5-6 shoe-last axes (Vencl 1999, 60 f.). So it is clear that we cannot assume any single function of the artefacts. In Danish, southern Swedish and northern German Ertebølle areas the imported shoe-last axes are thought to have had value and the function of a display item (Fischer 2002, 374), as their practical sharpness and durability did not exceed the local flint and greenstone axes. Still, the blade damages demonstrate that they were used in a practical way, often their butts are broken and huge flakes have been removed from the surfaces, in some cases it is evident that the biggest destruction traces have been polished over, the fragments have often been reworked, new shaft-holes cut (Fischer 2002, 374, fig. 22.17, 376). Shoe-last axes show successfully how artefacts can have prime value (costly material) as well as use value (practical and long-term exploitation) at the same time. According to John Chapman, it would be most useful to determine a special group of artefacts, the categorizing of which would be based on their ambiguousness - a tool-weapon. Although the only documented use of the Danubian shoe-last shaft-hole axes is murder, Chapman claims that the analysis of damage traces reveals clearly that some of them were used for heavy woodwork. An individual biography of a single tool-weapon, for example an axe, could involve killing several enemies as well as building a long-house (Chapman 1999, 107 f.).

Thus, the spheres practical/symbolic, domestic/ritual share common meaninggiving schemes and use the same symbols, but their meaning and interpretation depend on their social context. While ritual comprises a conscious social act of cosmogony where symbols and symbolic actions are used to create religious meanings, the same symbols appear in domestic life because they are popular means in expression and understanding (Garwood et al. 1991, viii). So, the final outcome of classifying artefacts and their functions into mentioned spheres are rigid and parallel categories. Richard Bradley and Mark Edmonds in their research of the working places of flint axes believe that although the morphology of the so-called abnormal (i.e bigger and more beautiful axes that are interpreted as ceremonials and valuables) axes adds a new dimension to the research, it does not give a sufficient basis for straightforward interpretations (Bradley \& Edmonds 1993, 48 f.). For example Jimmy Strassburg, in his attempt to obscure the spheres, has gone even further: in case of thin-butted flint axes he has emphasized their rituality in every aspect, which starts with choosing the material, continues with shaping and grinding and ends with using. According to Strassburg, every axe has a biography analogous to a person and in addition to serving as a ritual leader 
or an exchange item, its most common career involved everyday actions like felling trees, building, being used as a weapon, butchering big game and other activities that should not be called profane (Strassburg 1997, 165).

To sum up, in the following I will stick to a starting point that the shaft-hole axes, including boat-shaped axes of the $\mathrm{CWC}$, cannot be classified in rigid categories on the basis of their looks and supposed function. Such heterogenic material as shaft-hole axes are much easier to classify on the basis of their contexts, although also the latter are dubious and not comprehensive. The spheres I consider valid contexts for shaft-hole axes at this point are the following: grave, settlement site, offering place and/or a place for conducting certain rituals, and secondary context. The kind of contextual perception sheds light on the possible functions of the artefacts and thereby on people who were physically related to them.

At this point one should regard the doctoral thesis of Magnus Andersson (2003) as comparative material, where the author observes the Middle Neolithic landscape of western Scania and divides the archaeological remains into four categories: settlement site, grave, offering place and central place (sw. Samlingsplatser). At the same time he accepts that these rigid categories are irrelevant just as for the people the adjectives used by scientists like social, economical, mental, did not play any role. Therefore one can find human bones also from settlements and offering places, thus grave is not the only place to "preserve" the dead. Similarly, offering pits can be detected in settlement sites. But the categorizing is necessary if one wants to create even a slight meaning in prehistory, because every place still possesses a primary function and human activities (living, cooking, offering, burying) appear in many different places, although from time to time at exactly the same (Andersson 2003, 44). So, contextual approach itself adds an inevitable tendency to the research to divide the contexts into profane and sacred ${ }^{4}$ and thereby ascribe function and meaning to items that have been found there. For example, Andersson says that a house is not just a place to sleep and eat. Cultural norms accompany every action, building a house, ploughing the field, using a tool are all transformative activities that required certain rituals. And these rituals took place on different social levels, from collective to individual (Andersson 2003, 45). In itself, it seems from the abovementioned that defining the terms ritual and profane does not contribute much, as we cannot follow the meaning of the item through its context anyway - an artefact found from a clear profane context could actually be of sacral ulterior motive and vice versa. ${ }^{5}$ At this

4 At this point a question is justified whether the contextual approach to observe the material is somehow better or "more right" than by form or function, because our interpretations are nevertheless laden with our understanding of sacral and profane, ritual and practical, domestic and wild, prestigous and everyday.

5 According to Bradley, archaeologists like to regard artefacts as routinely discarded, when their use was over. This of course makes the claims about the character and role of material culture in social life questionable (Bradley \& Edmonds 1993, 8), but at the same time it simplifies the interpretation of material. But, would we get futher and to a better or "more right" outcome with our interpretations if we considered every activity to be ritual behaviour as Strassburg does? 
point we should mention for example the so-called abandonment practices that are known from the areas of Maglemose Culture (Strassburg 2000, 109). A ground stone axe, which was found from a hearth from a settlement site of Sindi-Lodja III (Estonia), is an example of the same tradition. There is no reason to claim that items found from settlement sites are of a more profane character than grave-goods or sacrificial finds. Andersson emphasises that there is no point in distinguishing between ritual and profane during prehistory, at least the Stone Age, as ritual activities were closely related to daily activities like hunting, fishing, agriculture, thus dividing life spheres to ritual or profane is futile in case of a society where every life aspect is strongly connected to the other (Andersson 2003, 185).

Luckily most of the items obtained from a certain context, its place and character, suggest whether they are a more formal or informal deposition. But we should always keep an open mind.

\section{Grave as a possible deposition context}

Every culture treats their dead with respect, relying the ancient idea of Afterlife. This idea obviously motivated the forming of religion in human cultures (see Danesi \& Perron 2005, 39). That is why the graves are places with a strong religious background.

Probably a part of the stone shaft-hole axes comes from graves as well. Among Estonian boat-axes only a comparatively small part has been found in graves, but in case of later shaft-hole axes, none were found in grave at all. According to Jaanits a certain part of shaft-hole axes has been collected from destroyed graves or those with unnoticed skeletons (Jaanits et al. 1982, 107). In case of Finnish material, for example, Matti Huurre believes that out of a thousand boat-axes an overwhelming majority are from graves (Huurre 1998, 276). The possibility that a considerable part of Estonian shaft-hole axes might come from graves is opposed by the fact that only the earliest types of boat-axes have been found from graves. If we were dealing with axes from destroyed graves, the proportion of stray finds should be equal among all shaft-hole axes. Thus probably only a limited amount of axes were placed in graves, and another kind of deposition practice was dominating but it had to exist already from the very start of the CWC.

At this point a question of course emerges, namely - why were the axes placed into a grave, or why and how were the axes selected or vice versa, a grave was perhaps selected for an axe? A single indication is offered by research of simple shaft-hole axes by Per Lekberg who suggests short and whole but severely worn axes often with extremely damaged surfaces as possible grave axes (Lekberg 2002, 120). On the other hand, Helena Knutsson mentions axes made specifically for burial rituals and grave goods (Knutsson 1995, 206) during the CWC.

Axes obtained from graves in Estonia are whole and as a rule considerably worn and damaged. But differently from Swedish material, the axes are all relatively long and proportional. The latter indicates that they have not been used for hard 
woodwork as this would demand repeated sharpening which would not preserve the proper proportions of the axe. Estonian boat-axes from graves are all more than $15 \mathrm{~cm}$ long and with worn surfaces. Thus the material of our graves does not support the suggestion of Lekberg or the one of Knutsson. Nevertheless, it seems that boat-axes have not been used for heavy woodwork, since according to my own experiments the axes do not break easily into two halves at the shaft-hole, rather tiny pieces are constantly removed from the blade which forces frequent sharpening and results in a deformed shape of the artefact. The latter phenomenon is not observed among the Estonian grave material. It is surprising that no simple or late shaft-hole axes have been added to the grave. I suggest that for some time part of boat-axes possessed a different depositional practice as a grave good. Nevertheless, the custom to place axes into graves was disappearing by the early 2nd millennium BC everywhere on the eastern coast of the Baltic Sea, as indicated by the Early Bronze Age cemetery with pit-graves of Kivutkalns in Latvia where none of the 268 graves contained any stone axes (Денисова et al. 1985).

The morphology of the axes from a documented grave and the information from find reports provide necessary data about a part of the stray finds as well. As a rule, the axes from Estonian Corded Ware Culture cemeteries represent Külasema or Karlova type, they are on the average $18-19 \mathrm{~cm}$ long, proportional and show little trace of age. Considering these parametres we could count 168 axes (20-21\% of all 820 stone axes) from graves. Five cases for a possible grave may be distinguished: (1) the find report mentions bone finds in addition to an axe; ${ }^{6}$ (2) the axes look like "burial axes" and have been found from a higher place on the ground (a gravel/sand hill, gravel/sand career, etc.); (3) the axes have been found next to or under a boulder; (4) other items have been found, provided that the artefacts are complete; (5) the depth of the finding place of the axe stays between 30 and $60 \mathrm{~cm}$.

\section{Settlement site as a possible deposition context}

According to the earlier treatments in Estonia, the found shaft-hole axes indicated the closeness of a settlement site (for example Lang 1999a, 333). For some of stray found stone axes this could definitely be the case. Many researchers in Estonia and the neighbouring countries have pointed out that axe fragments can often be found from settlements, but whole axes are rare (for example Malmer 1962, 266; Loze 1979, 68 ff.; Lekberg 2002, 168 ff.; Янитс 1959, 51; Lõugas 1970a, 340; Kriiska \& Saluäär 2000, 16). Also the ethnographical parallels prove that finding whole artefacts from settlements seldom happens. People care for their tools, personal and prestige items, thus they were hardly ever discarded or left unmended. A research of ethnographical hunter-fisher-gatherers has shown that

${ }^{6}$ Here and henceforth the examples to confirm the described cases are only provided in my master's thesis (Johanson 2006). 
the settlement context at the time the site was abandoned revealed organic remains, hearths, post-holes and the so-called expedient tools like stones for cracking nuts (Gregg et al. 1991, 150). It has been indicated that only in case of a sudden departure (attack, natural disaster) we might talk about bigger assemblages of usable items on settlement sites (Lönnqvist 2000, $81 \mathrm{f}$.). The axes are considered personal attributes by different indigenous nations (and I do not see a reason why it should not be considered in case of prehistoric people), like jewellery or clothing etc., and such items are taken along when the settlement is abandoned for good, but also when it is left for a season (Graham 1993, 33).

Although an indicator of a settlement site is usually a blade or a butt fragment of a stone axe, whole axes from settlements have been found as well. At this point we should turn to other unbroken artefacts from dwelling sites, like usable adzes, scrapers, etc. In case of scrapers they could easily have been lost in everyday rubbish because making a new one was not such a work-consuming business, but in case of adzes the possibility is already less credible. They are of course small and thus could be buried under trash, but not so easily when they were hafted (as they probably were). The ambiguous thing is finding them from strategically important places like hearths, as one is known from Sindi-Lodja III settlement site in south-western Estonia (Fig. 1). This would refer to a possibility of practices

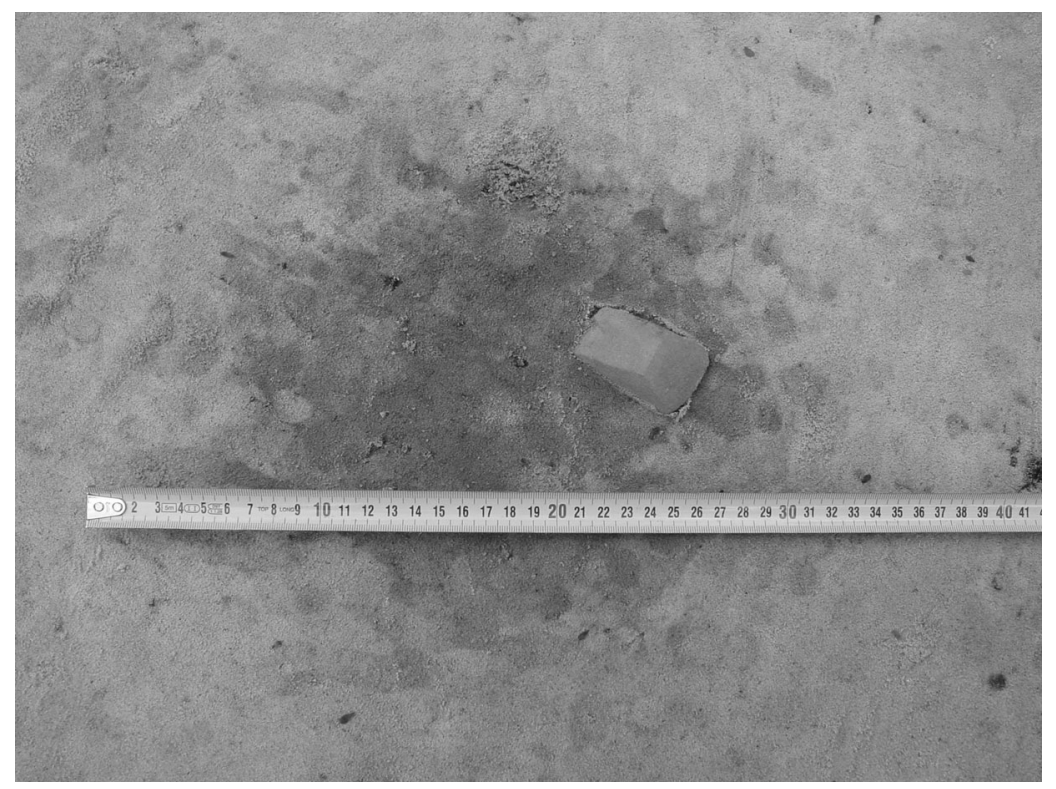

Fig. 1. A stone adze found from a fire-pit in the Late Neolithic settlement site of Sindi-Lodja III, southwest Estonia (PäMu 15425/A 2561: 3079).

Joon 1. Talb Sindi-Lodja III hilisneoliitilise asula tuleasemest Edela-Eestis. 
with a norm to make an offering including an item used on the site. An example of abandonment practices can be drawn from Maglemose Culture where certain concentrations of microliths and hearths surrounded by nuts could indicate traces of deserting patterns. The floors were cleaned some time before leaving but in some cases there heavy flint working in some areas prior to actual departure (Strassburg 2000, 109). An archaeological parallel from the south-western part of northern America from the 1st millennium AD indicates a certain abandonment practice, namely the roof of the abandoned house was set on fire and all usable items including valuable materials were left in the house and destroyed (Schlanger \& Wilshusen 1993, 94). A way of attaching oneself to a particular place is seen in the custom of the Funnel Beaker Culture in Sweden where postholes were filled with pottery, axes and other artefacts, including whole and broken ones (Svensson 1991, 97 ff.). There are more examples of ritual offerings in archaeological material while abandoning a settlement or a house (see for example Schiffer 1987, 66).

Four possibilities should be discussed when talking about unbroken artefacts on settlements: (1) the place has been left in a hurry; (2) a certain abandonment ritual; (3) some artefacts are left behind when return is expected in case of semisedentary settlement strategy; (4) the artefact has got lost inside the cultural layer. In case of the stone axes we could exclude the 3rd and 4th alternative since it was mentioned above that personal artefacts are not left behind and ethnographic hunter-fisher-gatherer cultures keep their household zones clean and have a special place for garbage, thus the accidental loss of completely usable artefacts is not an option (Panja 2000, 111). Considering the above said, it can be concluded that unbroken artefacts can be left in settlements in case of a sudden attack or an abandonment ritual.

Nevertheless, conscious behaviour should be expected in case of axe fragments as well. I presume that the axes, which took at least 20-25 hours to make (Fenton $1984,230)^{7}$ did not lose their importance when they broke. ${ }^{8}$ The butt fragments could be used as expedient tools but since they did not have unique use value, they were left behind when leaving the settlement. The blade fragments, on the contrary, still had use value proved by the second holes drilled in them and when moving to a new place, they were taken along. Paradoxically, the number of butt and blade fragments does not seem to confirm this hypothesis, since this is considerable even among the find material from the settlement sites. It might be suggested that the blade fragments left at the site had lost their use value because of microcracks that would cause the artefact's breaking. The butt pieces, on the other hand, could have been used "until the end". In any case, I believe that even the fragments were valuable enough and thus not simply discarded.

7 The author's own experiments showed that the time might be even longer when the producer is not so skilled (as could be expected when every man made an axe himself).

${ }^{8}$ Especially unbelievable is the suggestion of Kevin Leahy that the majority of the stone axes were in use as plough shares and were lost and left on the field during the work (Leahy 1986, 148). 
The fact that fragments are predominantly found from settlement sites offers a clue to at least a part of stray found axes. Thus, out of 820 stone shaft-hole axes gathered from Estonia, approximately 123 (14\% of all axes) could derive from a settlement site. The following cases should be regarded as potential settlements: (1) places where stone adze/adzes have been found in addition to a shaft-hole axe; (2) places where an unusable axe fragment is accompanied by flint and/or quartz flakes and pottery; (3) places where several axe fragments have been found. Unfortunately, no Stone or Bronze Age pottery has been found on survey trips to locate the find places of axes, so inspections have not established a place of producing and using stone axes. However, the Iron and Middle Age cultural layer is present in many find places, which leads to an assumption that maybe the number of axes with secondary context is higher than previously imagined.

\section{Sacrificial place as a possible deposition context}

When talking about sacrificial sites, nobody would probably doubt that offerings had a religious content: cultic behaviours and deities, communication with souls and the powers of dead ancestors (see for example Svensson 2004, 217; Sternquist 1997, 14), offerings can be included in different transition rites that demand communication with the spiritual world, yet sometimes they can be part of a social event, like peace treaties and marriages (Svensson 2004, 218). Traditional definitions mention two important aspects about offerings: they usually appear in wetland and have to include at least two artefacts. However, Per Karsten in his thorough work does not exclude a single deposition or a deposition on dry land as a possible offering (Karsten 1994), moreover, these are actually "formal" questions that simplify the understanding of offering but do not really reflect the possible variations of this behaviour. Whether it was placed into the ground for communicating with supernatural forces or maintaining social ties, it has nevertheless been a sacral act and therefore why not name any conscious act of deposition "an offering".

Several authors have tried to guess the morphology of the sacrificial axes. According to Lekberg, sacrificial axes are long and unused, sometimes blanks and rough-outs (Lekberg 2002). At the same time Karsten mentions that the appearing of fragmentary and damaged but reworkable axes into sacrificial assemblages is connected with single depositions (Karsten 1994, 189). Olausson also agrees that short and damaged axes appear as a single deposition, whereas long axes could be interpreted as caches (Olausson 1983, 22). Since according to the above, single

\footnotetext{
9 Still, another single-item deposition should be viewed at this point that cannot be labelled as religious - namely caching. An example is provided by Schiffer, who describes Duna farmers in New-Guinea who hide their axes used for clearing fields next to the patch, but can forget where they hid their property (Schiffer 1987, 79). Hiding valuables, including axes for safekeeping should be considered.
} 
offerings of axes could be found from wet areas as well as dry land, it seems difficult to distinguish between the stray finds referring to settlements, graves and sacrificial sites. The Scandinavian materials indicate that while the offerings of boat-axes almost unexceptionally appear in wetlands, the simple and late shaft-hole axes have been deposited on dry land. This in turn would provide a necessary hint for differentiating between graves and offering sites, since the present archaeological data knows boat-axes from graves. To differentiate between the axe fragments indicating a settlement site and an sacrificial site, it must be made sure wheather the fragment is reworkable or not, since useless fragments were probably never deposited as an offering but namely these are expected to be found in settlements. Thus it can be concluded that the offered axes appear singly in wetlands, they are short and can be fragmentary, cached axes appear on dry land, they are long, without damage, with big usage potential and there are usually several of them together.

Some possible specific offering motives may be discerned. (1) Offering was conditioned by a special landscape that could be important for individual arbitrary reasons only. Thus we cannot exclude depositions in places with no remarkable natural phenomena, for example some of the Sami offering sites (siejedde) could be situated on a flat and empty pasture with no "landmarks" (Bradley 2000, 6). In that case following the practice in Stone or Bronze Age is impossible. When the offering was regulated by certain norms, the practice is difficult, but still possible to follow. For example, the offered artefact could be orientated towards a particular landmark and be itself buried in a totally hidden site. (2) Deposition was conditioned by a need in society to set a certain limit (for example in case of death). The concept is closely connected with the axe as indicating a grave, though it is not placed inside the grave, rather it is placed in the ground on the border between the deceased and the settlement to prevent the dead leaving the grave. The concept here lies in the idea of axes as markers of certain borders borders between the dead and the living. The earlier researchers have supposed (Jaanits for example) that the cemeteries situated at some distance from the settlements during the Corded Ware Culture might refer to the fear for the dead. To some extent the position of the dead in the grave - sleeping or sometimes foetus position confirms the idea as it indicates that the dead had been tied up (to avoid their return). The dead in foetus position have been interpreted as tied together elsewhere as well (see for example Peressinotto et al. 2004, $57 \mathrm{ff}$.). It is possible that the axe was placed somewhere to mark the border between the territory of the dead and the living so that either side would remember not to cross the line. The axe could have belonged to the deceased but there is a possibility that a son (or some other close person) used his own tool to eliminate the dead. For certain items it is vital not to use them in an improper way. Artefacts that were used only in specific situations had to be taken out of circulation when this situation was over. The most adequate example could be the prohibition to inherit particular items that had to be destroyed when their owner died (Bradley 2000, 37). 
A stone axe could surely be one of these special artefacts that had to be eliminated after the death of its owner. Thus, there might be a graveyard for axes besides the graveyard for humans - the dead artefacts together with their dead owners and connected on a specific landscape. An example of two cemeteries - one for the people and the other for the individual important artefacts - is offered by a CWC cemetery in Sope, north Estonia, where altogether nine burials were found ${ }^{10}$ and none had boat-axes. At the same time, 150-160 m further, three stone shafthole axes were found (Fig. 2). It has been assumed that certain categories of deposition in settlements, graves or ceremonial centres demanded some other depositions on the border of the outside landscape. Thus every place on the cultural landscape would have an analogue on the natural landscape (Bradley 2000, 154). We could conclude from here that the dead were perceived in different ways on the territory of the living and the dead. For example, the deceased was buried on a cemetery (= the room of the dead) and his axe as his individual property and a highly symbolic item had to be deposited in the world of the living, either to simplify the elimination of the dead or the opposite, to make sure that the dead

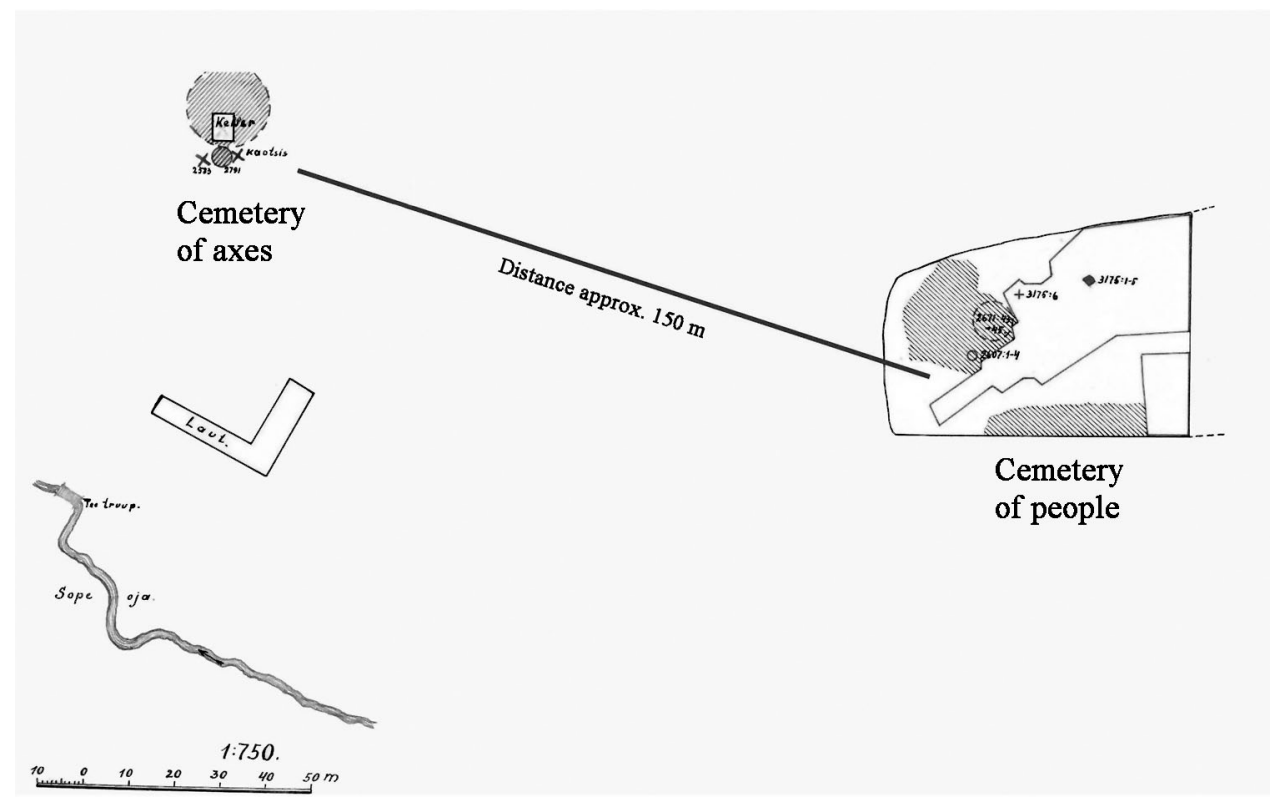

Fig. 2. An example of the separate graveyards for humans and for axes, Sope, northern Estonia. Drawing based on R. Indreko's 1933 excavation plan (original in the archive of the Chair of Archaeology at the University of Tartu).

Joon 2. Näide eraldi kalmistutest inimestele ja kirvestele. Sope, Põhja-Eesti. Joonise alus: R. Indreko 1933. aasta kaevamisplaan (originaal Tartu Ülikooli arheoloogia õppetooli arhiivis).

${ }^{10}$ It should be mentioned here that all have been found at the end of the 19th and the beginning of the 20th century, so there are no certain data about the site. 
stayed with the living and protected them with the power of their soul. At this point a certain link between two customs in the Neolithic could be followed: when during the Middle Neolithic Comb Ware Culture the dead were sometimes buried inside the dwellings or in close neighbourhood of the settlements, thus keeping them physically close, then during the Late Neolithic Corded Ware Culture the dead were physically kept away, but their personal attributes were brought closer to the living. ${ }^{11}$

Out of 820 stone axes, 65 offering finds and 11 caches $(8 \%$ and $1.4 \%$ respectively) can be distinguished. Whereas differentiating offering context is the most challenging, it can be mixed up with both burial (dry land offerings) as well as settlement contexts (offerings of fragmentary artefacts). (1) Nevertheless, sacrificial customs are indicated by wetlands - remarkable amount of axes has been gathered from lakes, rivers and bogs. (2) Offerings on dry land are noticed by visible landmarks - a boulder, a unique tree etc., many of which might not have survived. (3) Offering context can be suggested in case of the axes with the so-called ending use potential - worn, short, complete or broken, but definitely reworkable examples.

To sum up the discussion thus far, the conscious deposition of a single artefact might originate from an unnoticed grave or a stand for the grave, marking the border between the living and the dead; it could be an abandonment offer in a settlement site; or it could have been deposited for more individual and arbitrary reasons. All these alternatives concern the primary (Stone Age) context of the axes, but the secondary context that could be calculated for $10-15 \%$ of all stone shaft-hole axes, is definitely worth discussing further.

\section{Possible context of secondary deposition}

There is every reason to suppose that a considerable part of stone axes have been used several times after the Stone Age, some even continuously, even though the ways of using can be fundamentally different. The context where the artefact appears and through which it immediately acquires a certain meaning, was probably not intentional; moreover, this meaning did not have to be the motive why the artefact was produced in the first place. Despite the mentioned contextual confusion, it is important to distinguish between the secondary using and deposition of stray finds.

The secondary contexts can be divided into two: the early secondary context the stone graves of later prehistoric periods, starting from the Late Bronze Age until the beginning of the Middle Age in Estonia (the beginning of the 13th century); the later secondary context - the contexts of the Middle and Modern Age up to the present.

11 It has to be kept in mind, though, that there are no stone axes to be found from actual settlements themselves, so we are still talking about the wider space of the living and the dead. 


\section{The early secondary context}

As said before, the early secondary context includes various stone graves that in Estonia were constructed and used from the Late Bronze Age (around 1000 BC) until the end of prehistory (the first half of the 13th century AD). The stone axes in arhcaeologically excavated graves are represented only by a few examples: fragments have been found from the Tõnija Roman Iron Age and Piila Viking Age stone graves (Fig. 3) in Saaremaa, excavated by Marika Mägi, and Lülle Bronze Age shipsetting (Fig. 4) also in Saaremaa, excavated by Vello Lõugas (Lõugas 1970b). Other than that we have plenty records in archives gathered as oral tradition that mention finding stone axes from heaps and ruins of stone. While some might refer to cairns of stones collected from fields, a part of these, however, might indicate a stone grave. In case of Estonian material the few Stone axes from later graves turned out to be the simple ones, dating across a wide time span, but at least in one case (Lülle) can be contemporary with the grave. In Finland, on the other hand, we have for example the Late Neolithic CWC boat-axes from Hämeenkyrö Mahnala Lehtiniemi Late Iron Age stone grave (Asplund 2005). The adding of stone axes into later graves is a custom that is spread in a larger region than just Estonia: in Finland Käräjämäki in Eura, Peltokutila in Kalvola (more examples see Asplund in print), in Sweden axes have been found from both graves, as well as heaps of burned stones (skärvstenshögar), for example in Adelsnäs (Petersson 1998). Both the graves and heaps date back to the same time

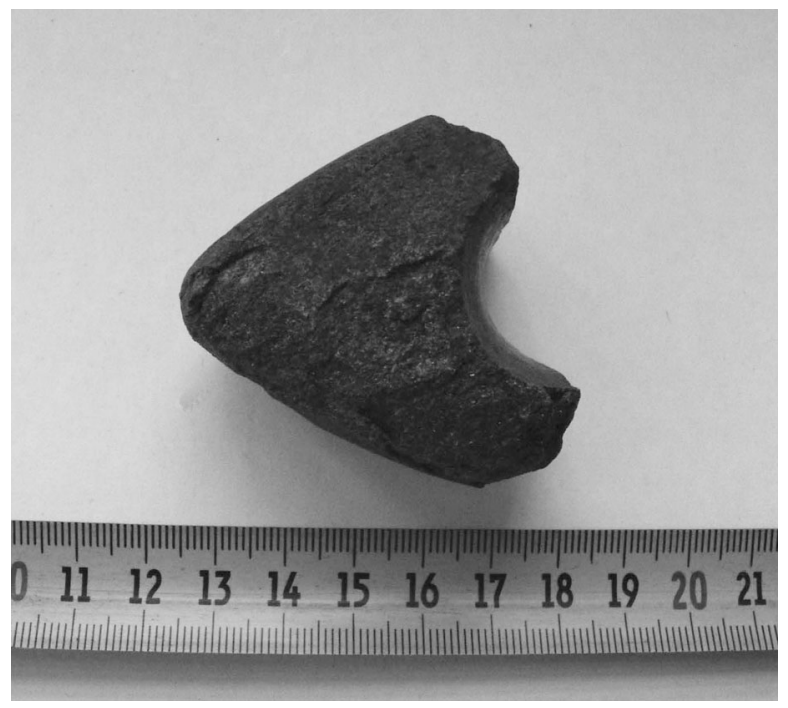

Fig. 3. Fragment of a stone axe from Piila Viking Age stone grave, Saaremaa (SM 10206/A 1468: 37).

Joon 3. Kivikirve katke Piila viikingiaegsest kalmest Saaremaalt. 


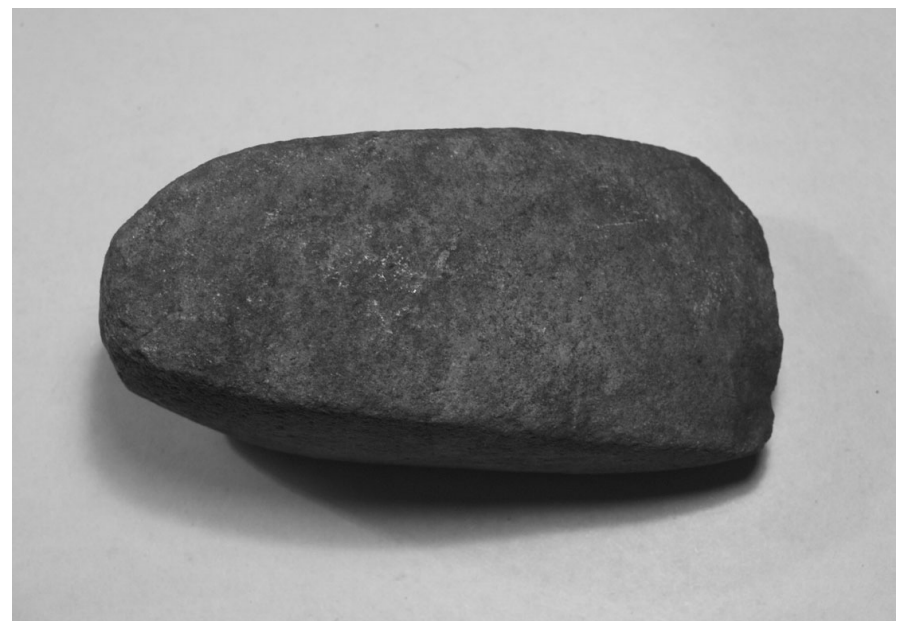

Fig. 4. Unfinished stone axe from Lülle ship-grave, Saaremaa (AI 4409: 31).

Joon 4. Lõpetamata kivikirves Lülle laevkalmest Saaremaalt.

and probably shared similar ritual behaviour (Petersson 1998, 12, 19). As the axes have not been placed into the graves to accompany a certain deceased person, there is a possibility that they were inserted into the filling of the grave in connection with the whole grave and not a single dead body. The axe might therefore be an object of magic which was supposed to protect the people of the whole community, the dead by adding the axe into the grave and the living through certain rituals conducted on the grave while erecting it. Where would this protective magic come from? At this point we should observe other Stone Age (or earlier) material in later graves. The amount of material is actually quite overwhelming. To mention a few: quartz processing debris (flakes and blades) from Uusküla grave from the Late Pre-Roman period (Lang 2000, 159) and Tõugu Bronze and Iron Age graves (ibid. 123), flint debris and corded pottery from the Late Iron Age grave in Madi (Selirand 1974, 45 ff.; Konsa 2003a), a harpoon head, stone adze, flint blades from Pähklimägi graves in Saha dated to the Roman period (Lang 1996, 246), quartz flakes from Tõnija Roman Iron Age and Piila Viking Age stone grave (Mägi 1997), etc. The similar behaviour has been recorded elsewhere as well, for example in Mecklenburg-Vorpommern in Germany the archaeologist Cornelius Holtorf documented the finds of Neolithic stone axes and pottery from Iron Age fire-pits, as well as Bronze and Iron Age graves (Holtorf 1998). Stone artefacts, flint and quartz tools and processing remains can be found from Swedish graves, as well as heaps of burned stones (Petersson 1998). Also in Finland flint and quartz has been found from the Iron Age graves (Uino 1997, 49). In addition, there are many stone graves erected directly on top of a Stone Age settlement site. To mention some: the CWC settlement sites under a tarand-grave in Võhma (Ots et al. 2003, 136) and a late stone cist or a tarand-grave in Kuninguste (Lõugas 1971), 
Late Comb Ware and a CWC settlement under a stone grave in Kaseküla (Kriiska et al. 1998, 40), probably a CWC settlement under Madi Late Iron Age stone setting (Konsa 2003a), possible Mesolithic settlements under Tandemäe stone graves in Võhma (Saluäär 2000), Tsiistre stone grave (Konsa 2003b) and Kõrenduse tarand-grave (Lavi 1978). All these customs seem to be a part of one and the same tradition, where ancestors and geneaologies were of utmost importance. It cannot be excluded either that earlier artefacts were regarded as something anomalous and not associated with forefathers.

There exists another alternative, namely that all the early material has been added with the soil when building the grave, and thus the fragments of stone axes in graves are put there as regular stones (as suggested for the axes from Piila and Tõnija stone graves by their researcher: Mägi, pers. comm. 08.06.2006). But lately it has been proposed that building a grave was not just a process of throwing stones into a heap but more a conscious and carefully planned act where every stone was in a way chosen for the grave. Thus we might expect to see a ritual behind building a stone-grave as well as burying there. The notion that stone graves have actually been more the places for conducting rituals than the places to bury the dead, the communication places between the dead and the living society, is quite new in Estonia (for example Lang 1999b; Mägi 2005). It has been supposed that every new generation built a new grave or a part of it (Lang 1996; 1999b). At the same time it seems likely that these graves were actually used for a long time but not everybody got to be buried in the grave (Lang 1996, 354). Thus the period between two burials could be very long, but the ruptures actually represent the confirmation of periodical genealogical legends (Jonuks, in prep.), something that was needed in society with a certain ancestors' cult.

It thus seems that certain rituals were conducted on the graves while adding the Stone Age material into the graves, possibly a myth was re-played every time a new dead body was buried there. ${ }^{12}$ When possible the graves were made right on top of an earlier settlement site in order to keep the ancestors close and ensure their protective powers. When there was no settlement site close, a handful of ancestors' material, taken somewhere further away, was put to the grave in the course of the ritual. It is even possible that when there was no way of obtaining the useful amount of Stone Age material ${ }^{13}$, it was produced on the spot - an example is provided by a stone grave of Uusküla in northern Estonia, where

12 At this point we should mention collective but especially cultural memory (see more on the topic Kõresaar 2001, 44) that stores some events that could have become also mythical and considers it necessary to somehow manifest them on the landscape. The event was probably the life of great-grandmothers and fathers and the myth within the event had to be re-played from time to time in the course of certain rituals. The abstract myth of ancestors has probably always existed, and when a place is found on landscape that constitutes a suitable background for the myth - a past settlement site perhaps - it will need a certain ritual behaviour, i.e. the founding of a grave.

13 Stone Age at this point is a contingent designation, as all earlier finds in later context might refer to the same tradition. 
altogether 286 pieces of quartz were found from the grave (Lang 2000, 159). On a closer look the quartz could be divided into two groups, one of which was produced as a result of intentional acts, the other seems to be struck into pieces on the spot. The other example comes from the stone grave in Ehmja in western Estonia, where a flint arrowhead of no recognizable analogue from Estonian Stone Age material (Fig. 5) was found in the filling of the grave - it thus seems that we can be dealing with an artefact made for the grave to represent the customs of ancestors. It should be pointed out that both of the mentioned graves date from the second half of the 1st millennium (Mandel 2003), a period when stone was definitely no longer used for making tools and weapons.

Having Uusküla grave freshly in mind, we should at this point mention the custom of breaking quartz on the graves. The tradition has been discussed in more detail by Carlie (1999) who gives an example from Sweden where broken quartz has been inserted into graves from the Bronze Age up to the Viking Age in amounts that vary from one piece to 500 (Tiraholm) up to 1000 kilograms (Sannarp) (Carlie 1999, 54). According to the researcher, quartz was especially important for its white colour and thus for the fertility cult, linking it with re-birth and ancestors. The white stones also seem to be of protective function whereas the lumps and flakes have often been built into the walls or placed as the upper layer on top of the graves to protect it (Carlie 1999, 55 ff.). The deliberate breaking of quartz has been considered possible by Estonian researchers as well (see Lang 2000, 123). There are many other examples that seem to refer to the quartz' special meaning, for example the description of Pliny the Elder of quartz as a unique and most precious "thunderstone" (cited in Myhre 1988, 321). Also the descriptions in the folklore archives of Estonia refer to the possibility that quartz lumps have been considered thunderbolts with special curative and protective properties. I do not

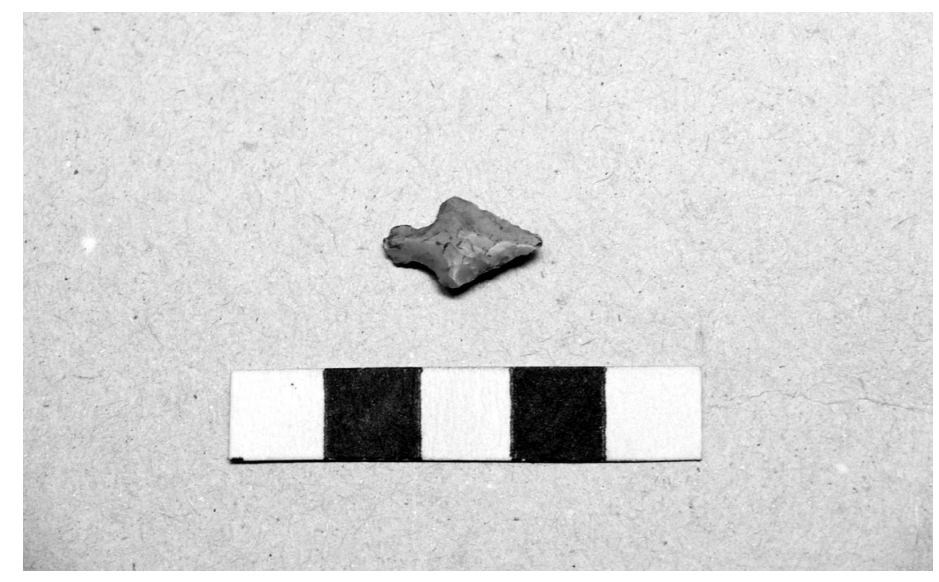

Fig. 5. Flint arrowhead from Ehmja stone grave (AM 26072/A 554: 390). Joon 5. Tulekivist nooleots Ehmja kivikalmest. 
want to oppose the idea of the special meaning of quartz, but I do not believe that all the quartz in the graves is there because of the special status of the rock. I rather consider the inserting of quartz, flint, stone axes, Neolithic pottery into later graves, as well as erecting a grave on a past settlement site, to be the reflections of one and the same tradition, in other words, to keep the handful from ancestors close. We cannot overrule the idea that the quartz might have been deliberately broken on spot, but even in this case the practice might reflect the actualization of a myth of ancestors.

In case of the stone graves it has been already proposed that they were not just burial places, but also places to conduct rituals, and the assumption that the nature of the rituals includes the ancestors' cult, is nothing new either. However, the Stone Age material in later contexts has practically never been analysed and to my mind it gives the assumption of the ancestors' cult a new and a more tangible direction. I hope I managed to demonstrate how a single item - a stone axe, for instance - can have so many different levels of understanding, which do not rely on their form or original function, but rather the context they appear in.

\section{The later secondary context}

The later secondary context of the stone axes is connected with their medieval and modern use, namely, the recognizing of stone axes as thunderbolts/thunderstones. At this point the widespread tradition should be examined more closely. The thunderbolt myth is known on a large area in Europe, America, Asia and Africa, but is missing in Australia. According to the legend, every time the lightning struck, a stone fell from the sky. The thunderbolts are usually Stone Age artefacts - axes, adzes, daggers, also scythes, etc., sometimes fossils, meteorites, sulphur crystals have been considered thunderbolts (see Carelli 1997, 399 ff.). According to the descriptions from Estonian folklore archives, also strike-a-lights or just regular round and extremely smooth stones have been called thunderstones. It was believed that you had to look for a thunderbolt in a place where lightning had struck and if you found it, you would be lucky in everything that you did. The thunderbolts were also used in healing: little pieces were broken or ground, the powder was eaten and fed to animals as a cure against different illnesses, rheumatism and toothache, to mention the most common problems (Fig. 6). Probably the most popular protective magical function that the thunderbolts had, was to make sure that lightning did not strike the houses or barns and kill people or animals. In Scandinavia the axes were kept on shelves, chests of drawers or in sacks, usually put away a somewhere special, e.g. bricked into the walls, placed under the sill or floor, attached into the ceiling above the bed (Carelli 1997, 404). There are examples from Estonian sources of keeping the archaeological findings, usually adzes, shaft-hole axes and strike-a-lights in a sowing-sack, pocket or under the staircase or the eaves. 


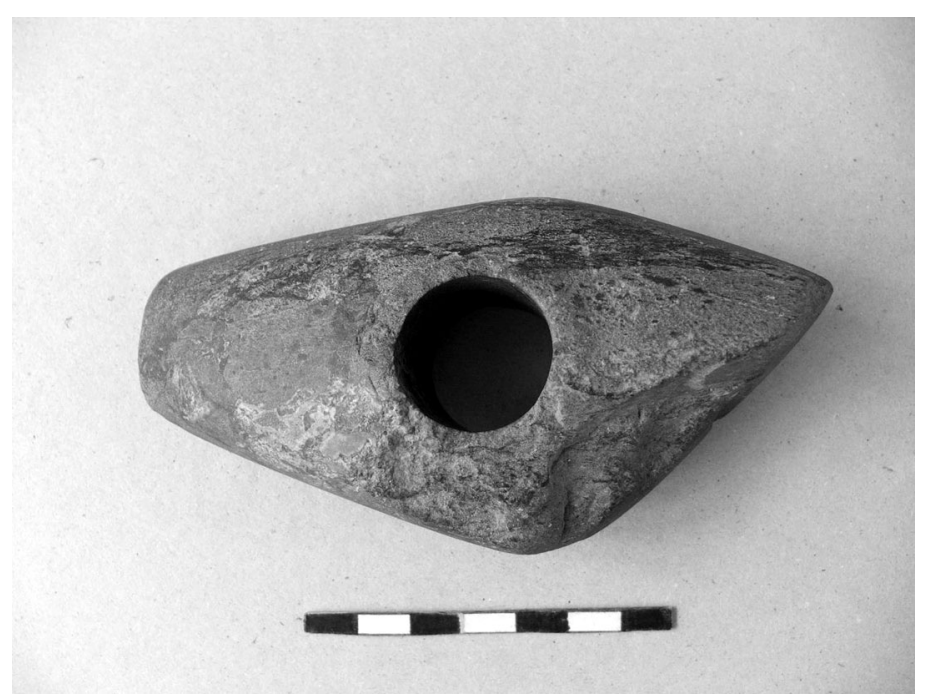

Fig. 6. Stone axe with traces of grinding - a possible "thunderbolt" from the village of Kõnnu (AI 6013).

Joon 6. Lihvimisjälgedega kivikirves - võimalik piksenool Kõnnu külast.

The idea of a thunderstone/thunderbolt is probably very old, as old as the need to explain things that happen around people. When lightning struck, people went to look for something special and no doubt they found something, even if it was just a regular but a really smooth stone or a fossilized trilobite or maybe a real fulgurite. At this point I cannot go more deeply into the intriguing problem, and have to ask at which point these Stone Age artefacts were regarded as thunderstones. The belief cannot have formed before their production for a practical reason had ceased for good. This has been suggested by different authors and dated to the beginning of the Iron Age (see for instance Salo 1990; Vasks 2003). As the making of an artefact from unflakeable stone like porphyrites, diabases, different greenstones (the most common raw material for shaft-hole axes) does not produce any or very little processing debris, because of the used techniques, pecking and grinding (Fenton 1984, 222), it is hard to establish the exact place and date of making the axes. For some reason we only know rarely few finds of the cores drilled out from the shaft-hole of the axes, but one of these, found from a fortified settlement of Asva and dated to the 1st half of the 1st millennium BC, could provide us with the approximate date of making a shaft-hole stone axe (Lang, in print). The same latest date - the end of the Bronze Age - has been proposed for Latvian material as well (ibid.). Latvian archaeologist Andrejs Vasks believes that the change how people saw stone axes has come about relatively quickly during the last centuries $\mathrm{BC}$, when the axes were first connected with symbolism and magic. There are many examples from Iron Age settlement 
sites in Latvia that reveal stone axes but they were not in use in the Stone or the Bronze Age and thus these can be related to a function other than practical, e.g. thunderbolts (Vasks 2003, 31).

In Estonia the majority of weapons and tools were made from iron already during the last centuries BC. It could take several generations, for an idea to become rooted. Thus, we might expect that theoretically the belief in stone axes as "thunderbolts" was present in the eastern Baltic region already in the first centuries $\mathrm{AD}$, or according to Estonian chronology, the Roman Iron Age. But as we do not have any written sources from this time, we cannot be sure that the belief really existed so early. We have examples of stone axe fragments and other Stone Age finds from the Late Iron Age contexts as well, and these could be interpreted as items connected with ancestors. It has been supposed, however, that graves lost their importance as places of conducting certain rituals connected with ancestors' cult starting from the Migration Period (5th century AD) (Jonuks, in prep). At the same time the change could not be so final and irreversible. We might be dealing with some transition phase between different magic ideas concerning the stone axe, but which all had a similar magico-protective background. Thus the belief in stone axes as thunderbolts could have formed in Estonia even as late as the Middle Ages. At this point certain Christian mentality should be mentioned that increasingly stressed the magic motifs and also introduced some new ones. It would be strange to imagine that the priests and crusaders who came here to bring the Christian religion, also introduced some moments of superstition. But it has been shown how medieval Catholicism, which was introduced here by strangers by force, in Latin, caused an increase of superstition and witchcraft (Vahemetsa 1961). Thus it would be wiser to presume that the belief in thunderbolts existed in Estonia in the background of several similar ideas already throughout the 1st millennium $\mathrm{AD}$, but became visible only with the Christian religion.

Anyhow, the belief in thunderbolts was strong all through the Middle and Modern Ages up to the 20th century. An excellent example is found from Lund, capital of an archbishopric and probably the most Christian medieval town in Scandinavia, where altogether 83 Stone Age artefacts, including many shaft-hole axes were found (Carelli 1997, 395 f.). The sill and eaves have been the most popular places to put the thunderbolt to keep away the lightning (see Carelli 1997, 405, fig. 5); the earliest date originates from London where an axe was found from the Migration period cultural layer that had probably been hanging under the roof (Merrifield 1987, 12). We have stone axes from medieval towns in Estonia as well, for example two items from the medieval cultural layer of Lihula and one from that of Tartu ${ }^{14}$ but these have been interpreted logically - there must have been a Stone Age settlement somewhere nearby where the axes reached the later

14 In addition axes have been found elsewhere from medieval towns (several examples from Tallinn and Tartu) and settlement sites (Viru-Nigula, Pada) but whether these have been regarded "thunderbolts" is difficult to prove. 
cultural layer by accident. The same has been supposed in regards to axes found inside or next to the foundation of later buildings in Estonia. I believe that we actually have to reconsider many of the contexts of axes that have been found near regarded barns, dwelling houses, etc. However, not all axes in clearly later secondary contexts should be considered as thunderbolts, possible antiquarian interest should be as well. For example, a collection of stone artefacts was found from the village of Vatku and initially interpreted as a Stone Age hoard, afterwards it was ascertained that it was actually a 19th century barn (see Lang 2000). Still, antiquarian interests can come under discussion only in the 18th-19th centuries and not before, as it was only at the beginning of the 18th century that the idea of thunderbolts as something man-made emerged in the heads of the naturalists of the time (see Clarke 1968, 5 ff.). But even if the antiquarians had explained the origin of thunderstones by the 19th century, common people only acknowledged it during the next, 20th century. An example is provided by G. Allen (1896/2005):

But the course of reasoning by which we discover the true nature of the stone axe is not one that would in any case appeal strongly to the fancy or the intelligence of the British farmer. It is no use telling him that whenever one opens a barrow of the stone age one is pretty sure to find a neolithic axe and a few broken pieces of pottery beside the mouldering skeleton of the old nameless chief who lies there buried. The British farmer will doubtless stolidly retort that thunderbolts often strike the tops of hills, which are just the places where barrows and tumuli (tumps, he calls them) most do congregate; and that as to the skeleton, isn't it just as likely that the man was killed by the thunderbolt as that the thunderbolt was made by a man? Ay, and a sight likelier, too (Allen 1896/2005).

Discerning the possible secondary usage and context of stray finds is complicated since neither their perceiving as a part of ancestors' cult nor protective magical "thunderbolts" has brought along clearly distinguished traces or changes in the axes' appearance. Out of 820 stone axes, 67 (8\% of all axes) may be associated with secondary context. On the basis of the parallels with stone graves, axes that have been found from stone heaps and clearance cairs, should be included here. In either case we might be dealing with stone graves that are difficult or impossible to recognize on landscape. Later secondary context is possible when an axe is found from the ruins of a deserted house in which case the axes have probably been regarded as "thunderbolts", the protective magic of which was the most effective when placed under the sill.

\section{Conclusion}

On the one hand the current article is about artefacts - things that have been collected from fields and forests, lakes and bogs, and even from people's barns and cellars. Lying on the museum shelves, they have never been actively interpretated. A widespread belief ruled for a long time that since they are found without any context there can really be nothing important or new that they can tell us. Luckily the situation is changing now and different profane and religious 
ideas are suggested for the deposition of single artefacts by considering their looks (damaged, intact, broken, etc.), their find context (settlement site, burial, offering place) and the geographic landscape in which they have been discovered. The present article handled three Stone Age contexts which could be assumed for the stray found shaft-hole axes: (1) single artefact might originate from an unnoticed grave or signify a grave, marking the border between the living and the dead; (2) it could be an abandonment offer in a settlement site; (3) or it could have been deposited for more individual and arbitrary reasons in places singularly special for the depositor that might never have had any visible peculiarities, or they have disappeared during the centuries. Secondary contexts - Bronze and Iron Age stone-graves as well as medieval and modern house foundations should be distinguished as revealing religious (i.e. superstitious) and magical ideas about the world. Unfortunately, although stray finds can be relatively informative, many controversies still remain. Let us take for example a whole axe from a settlement site - should we treat it as an (abandonment) offering or an artefact that accidentally got lost under the cultural layer? An axe fragment from a bog or a lake - is it the manifestation of a certain ritual or a practical farmer throwing away the useless piece? How can we ever tell the difference? But maybe making the difference is not the foremost thing to do? Maybe one should just be open-minded and not try to classify everything, as there might not be any categories? Maybe we should just accept that the daily life of the prehistoric people was intertwined with religious ideas, the same artefacts and same places were used for practical work as well as ritual activities, definitely most of the people conducted some small-scale ceremonies with the same tools they used to work in the fields and in forests. Maybe it would be wise to abandon the "profane" and the "religious"?

\section{References}

Allen, G. 1896/2005. Falling in love. With other essays on more exact branches of science. http://www.blackmask.com/thatway/books190c/flovdex.htm, last visited on April 30, 2006.

Andersson, M. 2003. Skapa plats i landskapet. Tidig- och mellanneolitiska samhällen utmed två västskånska dalgångar. (Acta Archaeologica Lundensia, Series in $8^{\circ}, 42$.) Almqvist \& Wiksell International. Malmö.

Andersson, M. 2004. Domestication and the first Neolithic concept. 4800-3000 BC. - Stone Age Scania. Significant Places Dug and Read by Contract Archaeology. Eds M. Andersson, P. Karsten, B. Knarrström \& M. Svensson. Riksantikvarie-ämbetets förlag. Skriften No 52. Malmö, 143-190.

Anfinset, N. 2000. Copper technology in contemporary western Nepal. A discussion of its form, function and context. - Form, Function and Context. Material Culture Studies in Scandinavian Archaeology. Eds D. Olausson \& H. Vandkilde. (Acta Archaeologica Lundensia, Series in $8^{\circ}, 31$.) Wallin \& Dalholm Boktryckeri AB. Lund, 203-212.

Appadurai, A. 1986. Introduction: commodities and the politics of value. - The Social Life of Things. Commodities in Cultural Perspective. Ed. A. Appadurai. Cambridge University Press. Cambridge, $3-64$. 
Asplund, H. 2005. Puikko puhki pilven? - Mustaa valkoisella. Ystäväkirja arkeologian lehtoria Kristiina Korkeakoski-Väisäselle. Eds V. Immonen \& M. Heimila. Turun yliopisto, arkeologia. Vantaa, 19-27.

Bradley, R. 2000. An Archaeology of Natural Places. Routledge. London.

Bradley, R. \& Edmonds, M. 1993. Interpreting the Axe Trade. Production and Exchange in Neolithic Britain. Cambridge University Press. Cambridge.

Carelli, P. 1997. Thunder and lightning, magical miracles. On the popular myth of thunderbolts and the presence of Stone Age artefacts in medieval deposits. - Visions of the Past. Trends and Traditions in Swedish Medieval Archaeology. Eds H. Andersson, P. Carelli \& L. Ersgård. (Lund Studies in Medieval Archaeology, 19. Riksantikvarieämbetet, Arkeologiska undersökningar, skrifter nr 24.) Almqvist \& Wiksell International. Stockholm, 393-417.

Carlie, A. 1999. "Sacred white stones". On traditions of building white stones into graves. - Lund Archaeological Review, 5. Lund, 41-58.

Chapman, J. 1999. The origins of warfare in the prehistory of central and Eastern Europe. Ancient Warfare. Eds J. Carman \& A. Harding. Sutton Publishing Limited. Gloucestershire, 101-142. Clarke, D. L. 1968. Analytical Archaeology. Methuen \& Co Ltd. London.

Coope, G. R. 1979. The influence of geology on the manufacture of Neolithic and Bronze Age stone implements in the British Isles. - Stone Axe Studies. Archaeological, Petrological, Experimental and Ethnographic. Eds T. H. McK. Clough \& W. A. Cummings. Council for British Archaeology. London, 98-101.

Danesi, M. \& Perron, P. 2005. Kultuuride analüüs. Valgus. Tallinn.

Earle, T. 2004. Culture matters in the Neolithic transition and emergence of hierarchy in Thy, Denmark: distinguished lecture. - American Anthropologist, 106: 1, 111-125.

Fenton, M. B. 1984. The nature of the source and the manufacture of Scottish battle-axes and axehammers. - Proceedings of the Prehistoric Society, 50, 217-243.

Fischer, A. 2002. Food for feasting? An evaluation of explanations of the neolithisation of Denmark and southern Sweden. - The Neolithisation of Denmark. 150 Years of Debate. Eds A. Fischer \& K. Kristiansen. J. R. Collis Publications. Sheffield, 343-393.

Garwood, P., Jennings, D., Skeates, R. \& Toms, J. 1991. Preface. - Sacred and Profane. Proceedings of a Conference on Archaeology, Ritual and Religion. Eds P. Garwood, D. Jennings, R. Skeates \& J. Toms. Oxford Committee for Archaeology. Oxford, v-x.

Graham, M. 1993. Settlement organization and residential variability among the Raràmuri. Abandonment of Settlements and Regions. Ethnoarchaeological and Archaeological Approaches. Eds C. M. Cameron \& S. A. Tomka. Cambridge University Press. Cambridge, 25-42.

Gregg, S. A., Kintigh, K. W. \& Whallon, R. 1991. Linking ethnoarchaeological interpretation and archaeological data. The sensitivity of spatial analytical methods to postdepositional disturbance. The Interpretation of Archaeological Spatial Patterning. Eds E. M. Kroll \& T. D. Price. Plenum Press. New York; London, 149-196.

Hodder, I. 1986. Reading the Past: Current Approaches to Interpretation in Archaeology. Cambridge University Press. Cambridge.

Holtorf, C. 1998. Monumental Past. The Life-histories of Megalithic Monuments in Mecklenburg-Vorpommern, Germany. University of Toronto. Scarborough. Online version: https://tspace.library.utoronto.ca/citd/holtorf/, last visited on April 30, 2006.

Huurre, M. 1998. Kivikauden Suomi: Sakari Pälsin, Aarne Äyräpään ja Ville Luhon muistolle. Otava Kustannusosakeyhtiö. Keuruu.

Jaanits, L. 1966. Venekirveste kultuuri asulatest Eestis. - Pronksiajast varase feodalismini. Uurimusi Baltimaade ja naaberalade arheoloogiast. Eesti Raamat. Tallinn, 60-65.

Jaanits, L., Laul, S., Lõugas, V. \& Tõnisson, E. 1982. Eesti esiajalugu. Eesti Raamat. Tallinn.

Johanson, K. 2006. Silmaga kivikirved Eesti arheoloogilises materjalis. Juhuleidude tõlgendusvõimalusi. Magistritöö. Manuscript in the Library of the University of Tartu. Tartu.

Jonuks, T. In prep. Groves in Estonian Prehistoric Religion. 
Karsten, P. 1994. Att kasta yxan i sjön. En studie över rituell tradition och förändring utifrån skånska neolitiska offerfynd. (Acta Archaeologica Lundesia, Series in $8^{\circ}, 23$.) Almqvist \& Wiksell International. Stockholm.

Knutsson, H. 1995. Slutvandrat? Aspekter på övergången från rörlig till bofast tillvaro. (Aun, 20.) Uppsala.

Konsa, M. 2003a. Eesti hilisrauaaja matmiskommete ning ühiskonna kajastusi Madi kivivarekalmistus. - Arheoloogia Läänemere maades. (Muinasaja teadus, 13.) Tallinn, 119-142.

Konsa, M. 2003b. The sites of Tsiistre and Kirikumäe in southeastern Estonia. - AVE, 2002, 144 152.

Kõresaar, E. 2001. Kollektiivne mälu ja eluloouurimine. - Studia Ethnologica Tartuensia, 4. Tartu, $42-58$.

Kriiska, A. \& Saluäär, U. 2000. Lemmetsa ja Malda neoliitilised asulakohad Audru jõe alamjooksul. - Artiklite kogumik. Pärnumaa ajalugu, 3. Pärnu, 8-38.

Kriiska, A., Lõugas, L. \& Saluäär, U. 1998. Archaeological excavations of the Stone Age settlement site and ruin of the stone cist grave of the Early Metal Age in Kaseküla. - AVE, 1997, 30-43.

Lang, V. 1996. Muistne Rävala. Muistised, kronoloogia ja maaviljelusliku asustuse kujunemine Loode-Eestis, eriti Pirita jõe alamjooksu piirkonnas, 1-2. (Muinasaja teadus, 4.) Tallinn.

Lang, V. 1999a. The introduction and early history of farming in Estonia, as revealed by archaeological material. - Environmental and Cultural History of the Eastern Baltic Region. (PACT, 57.) Strasbourg: Council of Europe, Division of Scientific Cooperation. Rixensart, 325-338.

Lang, V. 1999b. Kultuurmaastikku luues. - EAA, 3: 1, 63-85.

Lang, V. 2000. Keskusest ääremaaks. Viljelusmajandusliku asustuse kujunemine ja areng VihasooPalmse piirkonnas Virumaal. (Muinasaja teadus, 7.) Tallinn.

Lang. V. In print. Bronze Age and Early Iron Age in Estonia.

Lavi, A. 1978. Ausgrabungen auf dem Tarandgräberfeld von Kõrenduse. Resümee: Kaevamised Kõrenduse tarandkalmel. - TATÜ, 27: 1, 70-75.

Leahy, K. 1986. A dated stone axe-hammer from Cleethorpes, South Humberside. - Proceedings of the Prehistoric Society, 52, 143-152.

Lekberg, P. 2002. Yxors liv - Människors landskap. En studie av kulturlandskap och samhälle i Mellansveriges senneolitikum. Institutionen för arkeologi och antik historia. Uppsala.

Lillios, K. 1993. Regional settlement abandonment at the end of the Copper Age in the lowlands of west-central Portugal. - Abandonment of Settlements and Regions. Ethnoarchaeological and Archaeological Approaches. Eds C. M. Cameron \& S. A. Tomka. Cambridge University Press. Cambridge, 110-120.

Lönnqvist, M. 2000. Between Nomadism and Sedentism. Amorites from the Perspective of Contextual Archaeology. Juutiprint. Helsinki.

Lõugas, V. 1970a. Eesti varane metalliaeg (II a.-tuh. keskpaigast e.m.a. - 1. sajandini m.a.j.). Manuscript at the Institute of History in Tallinn. Tallinn.

Lõugas, V. 1970b. Sõrve laevkalmed. - Studia Archaeologica in memoriam Harri Moora. Valgus. Tallinn, 111-118.

Lõugas, V. 1971. Aruanne inspektsioonimatkast Saaremaale Tagavere ja Kuningate külla (Jaani khk.). Manuscript in the Chair of Archaeology of the University of Tartu.

Mägi, M. 1997. Aruanne arheoloogilistest kaevamistest Piila kiviringidega kalmistul Saaremaal, Kaarma kihelkonnas 7.-19. juulil 1997. Manuscript in the Chair of Archaeology of the University of Tartu.

Mägi, M. 2005. Mortuary houses in Iron Age Estonia. - EAA, 9: 2, 93-131.

Malmer, M. P. 1962. Jungneolithische Studien. (Acta Archaeologica Lundensia, Series in $8^{\circ}, 2$.) Almqvist \& Wiksell International. Lund.

Malmer, M. P. 2002. The Neolithic of South Sweden. TRB, GRK and STR. The Royal Swedish Academy of Letters History \& Antiquities. Stockholm.

Mandel, M. 2003. Läänemaa 5.-13. sajandi kalmed. (Eesti Ajaloomuuseum. Töid ajaloo alalt, 5.) Tallinn. 
Merrifield, R. 1987. The Archaeology of Ritual and Magic. New Amsterdam Books. London.

Myhre, B. 1988. Materielt som åndelig i pakt med tida. - Arkeologiske Skrifter fra Historiske Museum Universitet i Bergen, 4. Festskrift til Anders Hagen. Bergen, 310-324.

Olausson, D. S. 1983. Flint and Groundstone Axes in the Scanian Neolithic. An Evaluation of Raw Materials Based on Experiment. (Scripta Minora. Regiae Societatis Humaniorum Litterarum Lundensis, 1982-1983, 2.) Royal Society of Letters at Lund, CWK Gleerup. Lund.

Ots, M., Allmäe, R. \& Maldre, L. 2003. Rescue excavations at the Võhma X tarand-grave and the Võhma I Corded Ware Culture settlement site. - AVE, 2002, 131-143.

Panja, S. 2000. Mobility strategies and site structure: a case study of Inamgaon. - Journal of Anthropological Archaeology, 22, 105-125.

Peressinotto, D., Schmitt, A., Lecointe, Y., Pouriel, R. \& Geus, F. 2004. Neolithic nomads at El Multaga, Upper Nubia, Sudan. - Antiquity, 78: 299, 54-60.

Petersson, M. 1998. Adelsnäs. Åtvids socken, Åtvidabergs kommun, Östergötland. Rapport UV Linköping 1998: 19. Linköping.

Räf, E. 2000. Slaughtering holy cows? Studies of half-moon knives in women's graves on Öland. Form, Function and Context. Material Culture Studies in Scandinavian Archaeology. Eds D. Olausson \& H. Vandkilde. (Acta Archaeologica Lundensia, Series in $8^{\circ}, 31$.) Wallin \& Dalholm Boktryckeri AB. Lund, 239-251.

Renfrew, C. 1986. Varna and the emergence of wealth in prehistoric Europe. - The Social Life of Things. Commodities in Cultural Perspective. Ed. A. Appadurai. Cambridge University Press. Cambridge, 141-168.

Salo, U. 1990. Agricola's Ukko in the light of archaeology. A chronological and interpretative study of ancient Finnish religion. - Old Norse and Finnish Religions and Cultic Place-Names. Based on Papers Read at the Symposium on Encounters between Religions in Old Nordic Times and on Cultic Place-Names held at Åbo, Finland, on the 19th-21st of August 1987. Ed. T. Ahlbäck. (Scripta Instituti Donneriani Aboensis, 13.) Donner Institute for Research in Religious and Cultural History. Åbo, 92-190.

Saluäär, U. 2000. Kvartsileiud Võhma Tandemäelt: jäljed inimtegevusest - kui vanad? - Lang 2000, lisa II, 379-385.

Schiffer, M. B. 1987. Formation Processes of the Archaeological Record. University of New Mexico Press. Tucson.

Schlanger, S. H. \& Wilshusen, R. H. 1993. Local abandonments and regional conditions in the North American Southwest. - Abandonment of Settlements and Regions. Ethnoarchaeological and Archaeological Approaches. Eds C. M. Cameron \& S. A. Tomka. Cambridge University Press. Cambridge, 85-98.

Selirand, J. 1974. Eestlaste matmiskombed varafeodaalsete suhete tärkamise perioodil (11.-13. sajand). Eesti Raamat. Tallinn.

Shanks, M. \& Tilley, C. 1987. Social Theory and Archaeology. Polity Press. Worcester.

Sternquist, B. 1997. The Röekillorna Spring. Spring-cults in Scandinavian Prehistory. Almqvist \& Wiksell International. Stockholm.

Strassburg, J. 1997. Let the "axe" go! Mapping the meaningful spectrum of the "thin-butted flint axe". - The Kaleidoscopic Past. Proceedings of the 5th TAG Conference Göteborg, 2-5 April 1997. Eds A.-C. Andersson, Å. Gillberg, O. W. Jensen, H. Karlsson \& M. V. Rolöf. Göteborg University Department of Archaeology. Göteborg, 156-169.

Strassburg, J. 2000. Shamanic Shadows. One Hundred Generations of Undead Subversions in Southern Scandinavia, 7400-4000 BC. Stockholm University. Stockholm.

Svensson, M. 1991. A palisade enclosure in south-west Scania - a site from the Battle-Axe Culture. - Regions and Reflections. In Honour of Märta Strömberg. Eds K. Jennbert, L. Larsson, R. Petré \& B. Wyszomirska-Werbart. (Acta Archaeologica Lundensia, Series in $8^{\circ}, 20$.) Almqvist \& Wiksell International. Lund, 97-109. 
Svensson, M. 2004. The second Neolithic concept. 3000-2300 BC. - Stone Age Scania. Significant Places Dug and Read by Contract Archaeology. Eds M. Andersson, P. Karsten, B. Knarrström \& M. Svensson. (Riksantikvarieämbetets förlag, Skrifer No 52.) National Heritage Board, Archaeological Excavations Department. Lund, 191-248.

Thomas, J. 1991. Reading the body: beaker funerary practice in Britain. - Sacred and Profane. Proceedings of a Conference on Archaeology, Ritual and Religion. Eds P. Garwood, D. Jennings, R. Skeates \& J. Toms. Oxford Committee for Archaeology. Oxford, 33-42.

Tilley, C. 1996. An Ethnography of the Neolithic: Early Prehistoric Societies in Southern Scandinavia. Cambridge University Press. Cambridge.

Uino, P. 1997. Ancient Karelia: Archaeological Studies = Muinais-Karjala: arkeologisisa tutkimuksia (SMYA, 104.) Helsinki.

Vahemetsa, A. 1961. Eestlaste võitlusest ristiusu vastu XIII-XVI sajandil. - Religiooni ja ateismi ajaloost Eestis. Artiklite kogumik, II. Ed. E. Jansen. Eesti Riiklik Kirjastus. Tallinn, 150-172.

Vandkilde, H. 1996. From stone to bronze: the metalwork of the Late Neolithic and earliest Bronze Age in Denmark. (Jutland Archaeological Society publications, 32.) Árhus University Press. Moesgård.

Vandkilde, H. 2000. Material culture and Scandinavian archaeology: a review of the concepts of form, function, and context. - Form, Function and Context. Material Culture Studies in Scandinavian Archaeology. Eds D. Olausson \& H. Vandkilde. (Acta Archaeologica Lundensia, Series in $8^{\circ}, 31$.) Wallin \& Dalholm Boktryckeri AB. Lund, 3-49.

Vasks, A. 2003. The symbolism of stone work-axes (based on material from the Daugava Basin). Archaeologia Lituana, 4. Vilnius University Press. Vilnius, 27-32.

Vencl, S. 1999. Stone Age Warfare. - Ancient Warfare. Eds J. Carman \& A. Harding. Sutton Publishing Limited. Gloucestershire, 57-72.

Денисова Р., Граудонис Я. \& Гравэрэ Р. 1985. Кивуткалнский могильник эпохи бронзы. Рига.

Мозе И. А. 1979. Поздний неолит и ранняя бронза Лубанской равины. Рига.

Янитс Л. 1959. Неолитическое поселение Валма. Труды Прибалтийской обьединенной комплексной экспедиции. Москва, 33-77.

\section{Kristiina Johanson}

\section{ÜKSIKLEIDUDE PANUS INIMKÄITUMISE UURIMISEL KIVIKIRVESTE NÄITEL}

\section{Resümee}

On käsitletud 820 silmaga kivikirvest, mis on kogutud Eesti alalt valdavalt kontekstitult, nn juhuleidudena. Varreauguga kivikirveste valmistamise ning kasutamise algus on dateeritud neoliitikumiga - Eesti alal alates 3200. aastast $\mathrm{eKr}-\mathrm{ja}$ see on jätkunud läbi pronksiaja, tõenäoliselt kuni eelrooma rauaaja lõpuni aastatel $200-100 \mathrm{eKr}$, mil esemeid hakati valdavalt rauast valmistama. Vaatluse all olevad kivikirved jagunevad venekirvesteks, lihtsateks silmaga kivikirvesteks ja hilisteks silmaga kivikirvesteks. Nähtavasti on nende valmistamise puhul tegemist ühe ja sama traditsiooni erinevate etappidega. Nii võib eeldada sarnasusi nende tajumises ja kasutamise ning ladestamise reeglites. Seega näib kirveste 
leidmine enamikus üksikleidudena viitavat teatud sarnastele tegevustele ja nende taga olevatele motiividele. Juhuleidudena kogutud silmaga kivikirveste tõlgendamist on siiani enamasti välditud või peetud mittevajalikuks. Vaid harva on üksikleide peetud kas märgiks lähedal paiknevast asulakohast või säilimata matusest. Esemete valmistamine, kasutamine, töötlemine ja ladestamine on vaieldamatult seotud inimtegevusega. Seega on minevikus elanud inimeste tegevusmotiivide aimamise üheks võimaluseks erinevate religioossete ja profaansete ideede otsimine ühe esemeliigi, näiteks kivikirveste ladestamise taga, arvestades nende välimust (kahjustatud, terved, poolikud), leiukonteksti (asulakoht, matusepaik, ohverdamiskoht) ja maastikku.

Esemeid jagatakse uurijate poolt erinevatesse kategooriatesse, mis baseeruvad erinevatel vastuoludel, näiteks igapäevane $v s$ prestiižne, religioosne $v s$ materiaalne jne. Teravat vahet on tehtud praktiliste ja sotsiaalse ning religioosse funktsiooniga esemete vahel. Viimasel aastakümnel on rõhutatud, et materiaalsete esemete utilitaarsed ja sümboolsed ülesanded ei ole vastuolus, vaid pigem sõltuvad üksteisest ning kontekstist. On leitud, et kogu materiaalne kultuur on laetud sümboolse "tähendusega", mis teeb eristamise sakraalse ja koduse vahel ääretult raskeks ning ehk isegi mõttetuks. Tähendust ja funktsiooni pole mõtet teineteisest lahutada, sest need kujutavad ühe ja sama mündi erinevaid külgi ja teatud aja möödudes võib kunagi praktiliselt kasutatud eseme sümboolsest rollist saada selle uus funktsioon: näiteks on "piksenooled" - silmaga ning silmata kirved ja muud kiviaegsed esemed - oma kunagi praktilise (?) eesmärgi vahetanud kaitsemaagilise rolli vastu. Samuti ei ole võimalik lahutada eseme väärtust (väärtuslikkust, hinnalisust) selle funktsioonist ja vaikimisi oletada, et praktilise funktsiooniga ese oli väärtusetum. Esemete kategooriatesse jagamise asjatusest annavad tunnistust näiteks Skandinaavia esimesed vaskkirved, mille nii kaunistatud kui kaunistamata eksemplare on ühtmoodi praktiliselt kasutatud, ja Kesk-Euroopa paelkeraamikakultuuris levinud nn kingaliistukujulised kirved, mida on kasutatud nii tööriista kui sõjarelvana. Nii oleks kasulikum diagnoosida spetsiaalne esemerühm, mille kategoriseerimine põhineb nende esemete mitmemõttelisusel - tööriist-relv (tool-weapon). Seega sfäärid praktiline/sümboolne ja kodune/rituaalne jagavad tähendust andvaid üldisi skeeme ning kasutavad samu sümboleid, ent nende tähendus ja tõlgendus sõltuvad nende sotsiaalsest kontekstist. Kui rituaal hõlmab kosmogoonia teadlikku sotsiaalset akti, kus sümboleid ja sellealast tegevust kasutatakse religioossete tähenduste loomiseks, siis koduses elus ilmuvad needsamad sümbolid, sest need on populaarsed vahendid väljendamises ja arusaamises. Nii jäävadki esemete lahterdamise ja nende funktsioonide mainitud sfääridesse jagamise lõpptulemusteks lihtsalt paindumatud ja paralleelsed kategooriad.

On arvatud, et teatud osa või koguni enamik juhuleidudena saadud silmaga kivikirvestest pärineb haudadest, milles paraku ei ole inimluid säilinud. Kirveste morfoloogia alusel nende konteksti oletamine on Rootsi hilisneoliitiliste lihtsate vormide puhul osutanud, et kalmetest saadud kirved on eranditult terved, reeglina ka suhteliselt kulunud ja väga kahjustatud pinnaga "oma elu lõpul" olevad esemed. Rootsi neoliitiliste sõjakirveste puhul on oletatud ka kirveste tegemist spetsiaalselt 
matuserituaalideks. Eesti haudadest leitud kirved (eranditult nöörkeraamikakultuuri matusepaikade venekirved) erinevad mõlemast Skandinaavia puhul välja pakutud ideestikust. Siinsed kirved on pikad ja proportsionaalsed, sageli vaevu märgatavate terakahjustustega, samas on nende pind tugevalt kulunud, mis viitab kirveste võrdlemisi vähesele praktilisele kasutusele, ent pikaajalisele kaasaskandmisele. Kirveste morfoloogia osutab, et venekirveid ei ole tavaliselt kasutatud raskeks puutööks, sest eksperimentide järgi otsustades ei lähe kirved varreaugu kohalt kergelt katki. Pigem tähendab nende pidev teritamine kirve proportsioonide muutumist, mida aga Eesti matusekirveste hulgas ei kohta. Lihtsaid ja hiliseid silmaga kirveid ei ole kalmetesse pandud. See viitab, et kahele varaseimale venekirvetüübile sai osaks veidi teistsugune kohtlemine kui muudele silmaga kivikirvestele. Komme matta surnu koos kivikirvega taandus nähtavasti pärast mõnda aega kestnud praktikat, kadudes II aastatuhandel tõenäoliselt kõikjal Läänemere idarannikul peaaegu täielikult. Eestis teada olevatest nöörkeraamikakultuuri kalmistutest on leitud Karlova ja Külasema tüüpi venekirveid, mis on keskmiselt 18-19 cm pikad, proportsionaalsed ja oluliste kahjustusjälgedeta. Kalmekontekstiga võib Eesti alalt leitud 820 kirvest siduda 168 eksemplari (20-21\% kõikidest vastavatest esemetest). Kalmekonteksti võib eristada järgmiste situatsioonide puhul: 1) leiuteadetes on mainitud ka luude leidmist; 2) kirved on "kalmekirveste" mõõdu ning välimusega ja leitud kruusa- või liivakünkast (ka näiteks karjäärist, august jne) või madalamal maastikul eristuvast kõrgemast kohast; 3) kirved on leitud suure kivi kõrvalt või alt; 4) lisaks kirvele on leitud ka teisi esemeid - eeldusel, et esemed või vähemalt venekirves, on terved; 5) kirve leidmise sügavus jääb keskmiselt $30-60 \mathrm{~cm}$ vahele.

Arheoloogilistest asulakohtadest on leitud valdavalt katkisi kirveid. Ka etnograafiliste allikate kohaselt on asulatest tervete esemete leidmine haruldane. Inimesed hoolisid oma töö- ning tarberiistadest ja kahtlemata isiklikest ning prestiižsetest esemetest ja neid visati haruharva minema või jäeti katkisena maha. Seega on poolikute kirveste leidmine asulakohtadest seletatav nende kasutuspotentsiaali kadumisega. Nähtavasti ei jäetud ka kirve kanda purunemise kohta maha, vaid võeti asulasse kaasa, et rakendada seda n-ö improviseeritud tööriistana. Päriselt lahkudes jäeti see siiski maha. Terapoolmike säilinud kasutuspotentsiaalile viitab topeltaugu tegemise traditsioon; need võeti uude kohta liikudes kindlasti kaasa. Hüljatud asulasse maha jäetud teraosadel ei olnud aga oma lühikeste mõõtmete või mikropragude tõttu enam kasutuspotentsiaali, mistõttu uue augu puurimine oleks tõenäoliselt tähendanud kirve murdumist ja poleks seega töövaeva ära tasunud. Teatud juhtudel esineb terveid kirveid ka asulakohtades, mille seletuseks silmaga kivikirveste puhul võib välja pakkuda kaht: 1) ese on kiiruga põgenedes kogemata maha jäänud, 2) tegemist on omapärase lahkumisrituaaliga enne asula mahajätmist. Asulakontekstiga seostub Eestist saadud 820 silmaga kivikirvest 123 (14\% kõikide kirveste hulgast). Potentsiaalsete asulakohtadena tulevad arvesse: 1) kohad, kust lisaks kirvele on leitud kivitalb/-talbu; 2) kohad, kust lisaks kirve fragmendile on saadud ka tulekivi- ning kvartsikilde ja keraamikat; 3) kohad, kust on leitud korraga mitu silmaga kirveste katket. Kahetsusväärselt ei ole silmaga 
kivikirveste leiukohtade inspekteerimisel leitud kivi- ja/või pronksiaegset keraamikat, mistõttu ei ole suudetud inspektsioonidega kinnitada kivikirveste valmistamise ja kasutamise aegset elupaika. Küll aga on paljudes kohtades lokaliseeritud rauaja keskaegset kultuurkihti, mis võib viidata kirveste sekundaarsele kontekstile.

Enam levinud definitsioonide järgi piiratakse mõiste "ohver" märgalade ladestustega või seostatakse kindlate fikseeritud kultuskohtade või rohkem kui ühest esemest koosneva depositsiooniga. Samas eristatakse ka prominentse maastikuelemendiga seonduvaid kuivamaa ohvreid. Välistatud pole ka üksikleiu ohvriks nimetamine. Enamasti nähakse ohverdamise taga kommunikatsiooni jumaluste, esivanemate ja abstraktsemate hingedega, samas ei pea ohverdamise akt välistama mittereligioosse taustaga tegevusi, näiteks sotsiaalseid ja ilmalikke rituaale. Üksikdepositsioonide puhul ei saa kõrvale jätta ka nn turvalisuse kaalutlusel peidetud esemeid (banking caches). Hüpoteesi kohaselt võib kahjustatud ja fragmentaarsete esemete ilmumine ohvrileidudesse olla seotud üksikohvrite tekkimisega, kusjuures fragmentatsioon on eriti silmatorkav joon erinevate neoliitiliste silmaga kivikirveste puhul. Alternatiivse teooria kohaselt on lihtsad silmaga kirveste ohvrileiud valdavalt pikad ning kasutamata ja laetud realiseerimata kasutuspotentsiaaliga, samas kui lühikesed ja kasutatud ilmuvad kalmetes. Kuigi Eesti materjalis pole seni ohvrileide eristatud, võib ka siin täheldada üksiku kirvega ohvrileide (valdavalt lühikesed, potentsiaaliga fragmendid) ja peitleide (pikad, kasutamata). Ohverdamise võimalikud kohaspetsiifilised motiivid on: 1) ohverdamist tingis eriline maastik, mis võis olla oluline individuaalsetel põhjustel; 2) deponeerimist tingis vajadus piiri fikseerimise järele teatud situatsioonis (näiteks esivanema surma korral). Võimalik, et kirves asetatigi maha eesmärgiga seada piir lahkunu ja asula vahele, et takistada surnu hauast väljumist. Kivikirveste juhuleiud võivad viidata ka nn kirveste kalmistule, kus surnud esemed olid oma surnud omanikega spetsiifilisel maastikul ühendatud.

Eesti 820 silmaga kivikirve hulgas võib oletada 65 ohvri- ja 11 peitleidu (vastavalt $8 \%$ ja $1,4 \%$ kõikidest kirvestest): 1 ) ohverdamisele võib viidata märgala järvedest, jõgedest ja soodest-rabadest on läbi aegade kogutud märkimisväärne hulk silmaga kivikirveid; 2) kindlasti on ohverdatud kuivale maale, milline käitumine võib olla reguleeritud nähtavate maastikuelementidega - suur kivi, puu vms -, millest kõik ei pruugi olla säilinud; 3) ohvrikonteksti võib oletada ka nn lõppeva potentsiaaliga kirveste - kulunud, tervete või katkiste, ent ümbertöödeldavate eksemplaride - puhul.

Tõenäoliselt kasutati võrdlemisi suurt osa kirvestest pärast kiviaega korduvalt, mõnd ka järjepidevalt, ehkki kasutusviisid võisid ajas kardinaalselt muutuda. Laias laastus tuleb sekundaarse konteksti sees eristada varast ja hilist sekundaarset konteksti. Varane sekundaarne kontekst väljendub kivikalmetest saadud kivikirveste leidudes. Ehkki arheoloogiliste välitööde käigus on kivikirveid leitud vaid Piilast, Tõnijast ja Lüllest, märgivad leiuteated, et tõenäoliselt on neid ka mujalt saadud. Neid kivikirveid on vaadeldud kui eelmiste põlvkondade poolt kasutatuid, mida koguti, säilitati ja talletati kindlal ajal spetsiaalsetes kohtades. Esivane- 
mate mäletamisega seotud käitumuslikule taustale viitab ka muu varasem leiumaterjal hilisemates kalmetes: kvartsi- ning tulekivikillud, kiviaegne keraamika ja kristalsetest kivimitest lihvitud kiviesemed. Nähtuse teise osa moodustavad kindlasti kiviaegse asulakoha peale või vahetult kõrvale rajatud kivikalmed. Tegemist ei ole valdavalt nöörkeraamikakultuuri asulate ja tarandkalmete seosega, nagu varem oletati, vaid pigem võib rääkida kivikalmete ajal elanud inimestest, kelle jaoks varasem materjal - olgu nöör- või kammkeraamika, kvartsi- ning tulekivikillud ja kristalsetest kivimitest esemed - moodustas ühe terviku, milles tunti ära konkreetne minevik või müütiline esivanemate aeg. Varasema materjali lisamine hilisematesse kalmetesse viitab kultuurimälu kontseptsioonile, mis talletab mingid sündmused (mis võivad olla ka müütiliseks muutunud) ja peab vajalikuks neid maastikul manifesteerida.

Kivikirveste hiline sekundaarne kontekst seostub eelkõige nende kesk- ning uusaegse kasutusega ja väljendub uskumuses "piksenooltest". Usk "piksenooltesse/ piksekividesse" (äikese materialiseeritud kujusse, äikese produktsiooni) kui sellistesse pidi eksisteerima kindlasti varem kui konkreetseid kiviaegseid esemeid nendeks pidama hakati. Kiviajal valmistatud esemeid endid hakati oletatavasti "piksenoolteks" pidama pärast seda, kui neid otseselt inimtegevusega ei seostatud - Ida-Baltikumis rooma rauaajal. Samas võib viikingiaegsetest kivikalmetest leitud kivikirveid pidada pigem esivanematega seotud esemeteks. Kuigi on oletatud, et alates rahvasterännuajast on kalmed rituaalide läbiviimise kohana oma tähenduse kaotanud, ei olnud see protsess lõplik. Nähtavasti toimus "piksenoolte" aktsepteerimine järk-järgult ja erinevalt, vastavalt sellele, kuidas raud kasutusele ning omaks võeti ja vanad traditsioonid kaduma hakkasid. Läbi rauaaja võisid kivikirveste kohta käibida erinevad kaitsemaagilise taustaga ideed ja usu "piksenooltesse" meie piirkonnas võib teatud väljakujunenud vormis dateerida alles kesk- ja uusajaga. 